This item was submitted to Loughborough's Research Repository by the author.

Items in Figshare are protected by copyright, with all rights reserved, unless otherwise indicated.

\title{
Feasibility of using Y2Ti2O7 nanoparticles to fabricate high strength oxide dispersion strengthened Fe-Cr-Al steels
}

PLEASE CITE THE PUBLISHED VERSION

http://dx.doi.org/10.1016/j.matdes.2015.08.118

\section{PUBLISHER}

(C) Elsevier

VERSION

AM (Accepted Manuscript)

\section{PUBLISHER STATEMENT}

This work is made available according to the conditions of the Creative Commons Attribution-NonCommercialNoDerivatives 4.0 International (CC BY-NC-ND 4.0) licence. Full details of this licence are available at: https://creativecommons.org/licenses/by-nc-nd/4.0/

\section{LICENCE}

CC BY-NC-ND 4.0

\section{REPOSITORY RECORD}

Liu, Tong, Linbo Wang, Chenxi Wang, Hailong Shen, and Hongtao Zhang. 2015. "Feasibility of Using $\mathrm{Y}_{2} \mathrm{ti}_{2} \mathrm{O}_{7}$ Nanoparticles to Fabricate High Strength Oxide Dispersion Strengthened Fe-cr-al Steels". Loughborough University. https://hdl.handle.net/2134/19009. 


\section{Accepted Manuscript}

Feasibility of using $\mathrm{Y}_{2} \mathrm{Ti}_{2} \mathrm{O}_{7}$ nanoparticles to fabricate high strength oxide dispersion strengthened $\mathrm{Fe}-\mathrm{Cr}-\mathrm{Al}$ steels

Tong Liu, Linbo Wang, Chenxi Wang, Hailong Shen, Hongtao Zhang

PII: $\quad$ S0264-1275(15)30365-8

DOI: $\quad$ doi: $10.1016 /$ j.matdes.2015.08.118

Reference: JMADE 526

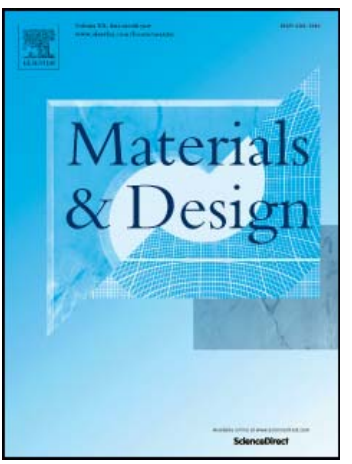

To appear in:

Received date: 25 February 2015

Revised date: 21 August 2015

Accepted date: 22 August 2015

Please cite this article as: Tong Liu, Linbo Wang, Chenxi Wang, Hailong Shen, Hongtao Zhang, Feasibility of using $\mathrm{Y}_{2} \mathrm{Ti}_{2} \mathrm{O}_{7}$ nanoparticles to fabricate high strength oxide dispersion strengthened Fe-Cr-Al steels, (2015), doi: 10.1016/j.matdes.2015.08.118

This is a PDF file of an unedited manuscript that has been accepted for publication. As a service to our customers we are providing this early version of the manuscript. The manuscript will undergo copyediting, typesetting, and review of the resulting proof before it is published in its final form. Please note that during the production process errors may be discovered which could affect the content, and all legal disclaimers that apply to the journal pertain. 


\title{
Feasibility of using $\mathrm{Y}_{2} \mathrm{Ti}_{2} \mathrm{O}_{7}$ nanoparticles to fabricate high strength oxide dispersion strengthened Fe-Cr-Al steels
}

\author{
Tong Liu ${ }^{\mathrm{a}, *}$, Linbo Wang ${ }^{\mathrm{a}}$, Chenxi Wang ${ }^{\mathrm{a}}$, Hailong Shen ${ }^{\mathrm{a}}$, Hongtao Zhang ${ }^{\mathrm{b}}$ \\ ${ }^{a}$ Key Laboratory of Aerospace Materials and Performance (Ministry of Education), \\ School of Materials Science and Engineering, Beihang University, Beijing 100191, \\ China \\ ${ }^{\mathrm{b}}$ Department of Materials, Loughborough University, Leicestershire, LE11 3TU, UK \\ *Corresponding author: Email address: tongliu@buaa.edu.cn; Phone/fax: +86 10 \\ 82316192
}

Abstract: Addition of $\mathrm{Al}$ can improve the corrosion resistance of oxide dispersion strengthened (ODS) steels. However, Al reacts with $\mathrm{Y}_{2} \mathrm{O}_{3}$ to form large Y-Al-O particles in the steels and deteriorates their mechanical properties. Herein, we successfully prepared $\mathrm{Y}_{2} \mathrm{Ti}_{2} \mathrm{O}_{7}$ nanoparticles (NPs) by the combination of hydrogen plasma-metal reaction (HPMR) and annealing. $\mathrm{Y}_{2} \mathrm{Ti}_{2} \mathrm{O}_{7}$ NPs with contents of 0.2 or 0.6 wt.\% were then added into the Fe-14Cr-3Al-2W-0.35Ti (wt.\%) steel to substitute the conventional $\mathrm{Y}_{2} \mathrm{O}_{3}$ NPs by mechanical alloying (MA). The $\mathrm{Y}_{2} \mathrm{Ti}_{2} \mathrm{O}_{7}$ NPs transformed into amorphous-like structure after $96 \mathrm{~h}$ MA. They crystallized with a fine size of $7.4 \pm 3.7 \mathrm{~nm}$ and shared a semi-coherent interface with the matrix after hot isostatic pressing (HIP) of the ODS steel with $0.6 \mathrm{wt} . \% \mathrm{Y}_{2} \mathrm{Ti}_{2} \mathrm{O}_{7}$. With the increasing $\mathrm{Y}_{2} \mathrm{Ti}_{2} \mathrm{O}_{7}$ content from 0.2 to $0.6 \mathrm{wt} . \%$, the tensile strength of the ODS steel increased from 1238 to $1296 \mathrm{MPa}$, which was much higher than that (949 MPa) of the ODS steel added with $\mathrm{Y}_{2} \mathrm{O}_{3}$. The remarkably improved mechanical properties of the Al-containing ODS steels were attributed to the increasing number density of $\mathrm{Y}_{2} \mathrm{Ti}_{2} \mathrm{O}_{7}$ 
nanoprecipitates. Our work demonstrates a novel route to fabricate high performance ODS steels with both high mechanical strength and good corrosion resistance.

Keywords: $\mathrm{Y}_{2} \mathrm{Ti}_{2} \mathrm{O}_{7}$ nanoparticles; ODS ferritic steel; Transmission electron microscopy; X-ray photoelectron spectroscopy; Mechanical properties

\section{Introduction}

The increasing global demand for energy coupled with a need to reduce carbon dioxide emissions caused by fossil fuels has revived interest in new-build nuclear energy generation. In order to improve the energy efficiency, the advanced nuclear power plants have been designed to operate at a higher temperature in various coolants including lead-bismuth eutectics (LBE) and super critical water (SCW) [1-4]. When it comes to selecting the materials for constructing the next-generation nuclear energy systems, the ODS ferritic steels get most of the attention because of their high creep strength and good irradiation and corrosion resistance [5-9]. Among various oxides, $\mathrm{Y}_{2} \mathrm{O}_{3}$ NPs are typically added into the ODS steels to improve their performances at high temperature, severe irradiation and corrosion environments in the fission and fusion power plants [10-12].

Since thermal stability and number density of the oxide dispersoids are responsible for the mechanical properties and irradiation resistance of the ODS steels, great efforts have been made to clarify the structure and dimension evolutions of oxide dispersoids during the fabrication of the ODS steels by using various techniques, such as transmission electron microscopy (TEM) and atom probe tomography (APT). It has been found that without $\mathrm{Al}$ addition, $\mathrm{Ti}$ can effectively refine the oxide particles in the ODS steels by combining with yttrium and oxygen to form stable Y-Ti-O oxides $\left(\mathrm{Y}_{2} \mathrm{Ti}_{2} \mathrm{O}_{7}, \mathrm{Y}_{2} \mathrm{Ti}_{2} \mathrm{O}_{5}\right.$ or non-stoichiometric compounds) with a size distribution from 2 to $30 \mathrm{~nm}$ [13-15]. Brocq et al. [16] observed that titanium, yttrium and oxygen 
directly transformed into Ti-Y-O nanoclusters in the ODS steel powder during MA, and the oxide clusters continued to nucleate and grow during annealing at $1073 \mathrm{~K}$. Lots of studies indicate that there exist coherent interfaces between the Y-Ti-O NPs and the matrix, which lead to the high mechanical properties of the ODS steels. For example, Ramar et al. [17] claimed that the dispersed Y-Ti-O NPs were semi-coherent with the matrix of EUROFER97 steels. Wen and co-workers [18] found that $\mathrm{Y}_{2} \mathrm{Ti}_{2} \mathrm{O}_{7}$ NPs possessed lattice coherency with the matrix of Fe-14Cr-3W-0.3Ti-0.212 $\mathrm{Fe}_{2} \mathrm{O}_{3}-0.242 \mathrm{YH}_{2}$ steel according to TEM observation. On the basis of the scanning TEM images and Fourier transform patterns, Hirata et al. [12] determined the orientation relationship between the $b c c$ ferrite matrix and the non-stoichiometric Y-Ti-O compound as $(\overline{110})_{\mathrm{bcc}} / /(002)_{\mathrm{oxide}}$ and $[110]_{\mathrm{bcc}} / /[110]_{\mathrm{oxide}}$. Thus, it has been concluded that the stable and fine Y-Ti-O oxides, which can form good lattice coherence with the matrix, play the critical role in enhancing the mechanical properties and irradiation resistance of the ferritic ODS steels without $\mathrm{Al}$ addition.

On the other hand, $\mathrm{Al}$ has been recognized as an important alloying element to improve the corrosion resistance of the high-Cr ODS steels for the generation IV fission power plants [19-23]. The addition of Al into the ODS steels resulted in high resistance to LBE corrosion even after an exposure for $5000 \mathrm{~h}$ due to the formation of a dense alumina layer on the surface of ODS steels [20]. Kimura and coworkers [22] showed that the addition of 4 wt.\% Al remarkably enhanced the corrosion resistance of $16 \mathrm{Cr}$-ODS steel in SCW by forming stable alumina layer on the surface. Recently, our group demonstrated that oxidation resistance of the $16 \mathrm{Cr}$-ODS steel at $1323 \mathrm{~K}$ was improved more than three times by adding 4 wt.\% Al [7]. Although these Al-containing ODS steels, such as PM2000 and MA956, can meet the corrosion 
resistance requirements, the degraded strength due to the thermodynamically preferable formation of the large Y-Al-O oxides $(5-100 \mathrm{~nm})$ instead of the fine Y-Ti-O oxides $(2-30 \mathrm{~nm})$ restrains their wide applications [24-26]. It has been proved that in the Al-containing ODS steels, Ti is unable to combine with $\mathrm{Y}$ and $\mathrm{O}$ to form Y-Ti-O complex oxide NPs during MA due to the fact that the formation enthalpy of Al oxide $(-800 \mathrm{~kJ} / \mathrm{mol})$ is higher than that of Ti oxide $(-770 \mathrm{~kJ} / \mathrm{mol})[22,27]$. Thus, different types of Y-Al-O complex oxides are generated in the Al-containing ODS steels through the polymorphic transition reactions at different consolidation conditions.

The relatively low strength of the Al-containing ODS steels limits their lifetime in the corrosive operation environments. It has been found that the size of oxide dispersoids cannot be effectively reduced by just decreasing the consolidation temperature [28]. Therefore, it is challenging to control the structure and size of the oxide dispersoids in order to further enhance the performance of the Al-containing ODS steels. In our previous study, we added $\mathrm{YH}_{2} \mathrm{NPs}$ to create the fine $\mathrm{Y}_{2} \mathrm{Ti}_{2} \mathrm{O}_{7}$ dispersions in the Fe-Cr-Al ODS steels. However, a certain amount of Y-Al-O NPs still remained [29]. In this work, we directly introduce $\mathrm{Y}_{2} \mathrm{Ti}_{2} \mathrm{O}_{7} \mathrm{NPs}$ in the Al-containing ODS steels by MA in order to prevent the formation of Y-Al-O particles and decrease the size of the oxide dispersions. To clarify whether $\mathrm{Y}_{2} \mathrm{Ti}_{2} \mathrm{O}_{7} \mathrm{NPs}$ decompose or become amorphous state during MA, we design a Fe-20 wt. $\% \mathrm{Y}_{2} \mathrm{Ti}_{2} \mathrm{O}_{7}$ model alloy to study the morphology change and structure evolution of these $\mathrm{Y}_{2} \mathrm{Ti}_{2} \mathrm{O}_{7}$ NPs. Moreover, the ODS steels (Fe-14Cr-3Al-2W-0.35Ti, wt.\%) with 0.2 and 0.6 wt.\% $\mathrm{Y}_{2} \mathrm{Ti}_{2} \mathrm{O}_{7}$ were prepared by MA and HIP techniques to investigate the effect of the $\mathrm{Y}_{2} \mathrm{Ti}_{2} \mathrm{O}_{7} \mathrm{NPs}$ on the microstructure and mechanical properties of the Al-containing ODS steels. For comparison, the conventional ODS steel with composition of Fe-14Cr-3Al-2W-0.5Ti- $0.35 \mathrm{Y}_{2} \mathrm{O}_{3}$ (wt.\%) was prepared by MA and HIP as well. The 
structure and size evolution of $\mathrm{Y}_{2} \mathrm{Ti}_{2} \mathrm{O}_{7}$ NPs in these ODS steels are discussed, and the enhanced tensile strength is interpreted in term of Orowan strengthening theory.

\section{Experimental}

The Y-50 at.\% Ti master alloy of $30 \mathrm{~g}$ was produced by arc melting yttrium and titanium ingots (purity $\geq 99.9$ wt.\%) for four times in Ar atmosphere (99.999\%). Then, the HPMR method was used to prepare the Y-Ti hydrides NPs by arc melting the Y-50 at.\% Ti master alloy at a current of $300 \mathrm{~A}$ in $0.05 \mathrm{MPa} \mathrm{Ar}$ and $0.05 \mathrm{MPa} \mathrm{H}_{2}$. The process of HPMR was described in detail elsewhere [30]. The hydride NPs were collected from the reaction chamber and were subsequently annealed at $1173 \mathrm{~K}$ in a furnace for $1 \mathrm{~h}$ in air to obtain $\mathrm{Y}_{2} \mathrm{Ti}_{2} \mathrm{O}_{7} \mathrm{NPs}$. These NPs were used as starting powder to substitute the conventional $\mathrm{Y}_{2} \mathrm{O}_{3}$ NPs for fabricating the ODS steels. The compositions of the model alloy and the commercial ODS steels are shown in Table 1. Hereafter, the samples with 0.2 wt. $\% \mathrm{Y}_{2} \mathrm{Ti}_{2} \mathrm{O}_{7}, 0.6$ wt. $\% \mathrm{Y}_{2} \mathrm{Ti}_{2} \mathrm{O}_{7}$ and 0.35 wt. $\% \mathrm{Y}_{2} \mathrm{O}_{3}$ are referred to as YT-0.2, YT-0.6 and Y-0.35, respectively. YT-0.6 and Y-0.35 with different contents of oxide NPs were designed to achieve the same nominal composition of Fe-14Cr-3Al-2W-0.5Ti-0.276Y (wt.\%). The high purity (> 99.9 wt.\%) elemental powders of Fe, $\mathrm{Cr}, \mathrm{Al}, \mathrm{W}$ and Ti were between 10 and $100 \mu \mathrm{m}$. The rod-like $\mathrm{Y}_{2} \mathrm{O}_{3}$ NPs (purity larger than 99.99 wt.\%) had a diameter of about $20 \mathrm{~nm}$ and a length of about $100 \mathrm{~nm}$ [31]. These metallic powders and oxide NPs were mechanically alloyed by a planetary ball mill with a ball to powder ratio of 15:1 at a rotation speed of $280 \mathrm{rpm}$ in $\mathrm{Ar}$ atmosphere. The Fe-20 wt. $\% \mathrm{Y}_{2} \mathrm{Ti}_{2} \mathrm{O}_{7}$ model alloy samples were milled for 2, 48 and $96 \mathrm{~h}$, respectively. The commercial ODS steel powders of YT-0.2, YT-0.6 and Y-0.35 were milled for 96 h. After MA, YT-0.2, YT-0.6 and Y-0.35 powders were consolidated at $1433 \mathrm{~K}$ by HIP under a pressure of $150 \mathrm{MPa}$ for $4 \mathrm{~h}$.

The structural analyses of these samples were carried out by X-ray diffraction 
(XRD) using a Rigaku X-ray diffractometer with monochromatic $\mathrm{Cu} \mathrm{K \alpha}$ radiation. The morphology and size distribution of the model alloy powders were observed by the CS-3400 scanning electron microscope (SEM) and the JEOL-JSM-2100F TEM. X-ray photoelectron spectroscopy (XPS) analysis was performed with the monochromatic Al source on the Escalab-250. Thermo gravimetry-differential scanning calorimetry (TG- DSC) measurement of the model alloy powders milled for $96 \mathrm{~h}$ was carried out between 298 and $1473 \mathrm{~K}$ at a heating rate of $10 \mathrm{~K} / \mathrm{min}$ and a flowing Ar of $400 \mathrm{ml} / \mathrm{min}$. The TEM samples (3 mm in diameter) of the ODS steels were prepared using the Struers Tenupol-3 double jet electro-polisher at $243 \mathrm{~K}$ with an electrolyte of $10 \% \mathrm{HClO}_{4}$ and $90 \% \mathrm{CH}_{3} \mathrm{CH}_{2} \mathrm{OH}$. The microstructures of the matrix, the oxides and the oxide/matrix interface were observed by high-resolution TEM (HR-TEM) at an accelerating voltage of $200 \mathrm{kV}$. The tensile properties of these ODS steels (three tests for each steel) at $298 \mathrm{~K}$ were tested using INSTRON-8801 at a strain rate of $6.7 \times 10^{-4} \mathrm{~s}^{-1}$. All the fractured samples were analyzed by SEM.

\section{Results and discussion}

\subsection{Preparation and characterization of $\mathrm{Y}_{2} \mathrm{Ti}_{2} \mathrm{O}_{7} \mathrm{NPs}$}

It was reported that a pure phase of $\mathrm{Y}_{2} \mathrm{Ti}_{2} \mathrm{O}_{7}$ can be fabricated by using $\mathrm{Y}_{2} \mathrm{O}_{3}$ and $\mathrm{TiO}_{2}$ powders in microscale through solid state reaction at a high temperature $(1573 \mathrm{~K})$ for a long time $(40 \mathrm{~h})$ [32]. Fig.1 (a) shows the XRD pattern of the Y-Ti hydrides annealed at $1173 \mathrm{~K}$ in air for $1 \mathrm{~h}$. All the diffraction peaks correspond to $\mathrm{Y}_{2} \mathrm{Ti}_{2} \mathrm{O}_{7}$ with pyrochlore structure (JCPDS: 42-0413, Space group: $\mathrm{F} d \overline{3} m$ ), indicating that pure $\mathrm{Y}_{2} \mathrm{Ti}_{2} \mathrm{O}_{7}$ has been successfully produced by annealing the hydrides NPs at much lower temperature $(1173 \mathrm{~K})$ and shorter time $(1 \mathrm{~h})$, compared to solid state reaction of microscale oxides. This is attributed to the high chemical reactivity of Y-Ti hydrides in nanoscale, see Fig. S1 in the Supplementary Material. Fig. 1 (b) displays the TEM 
image and the histograms of particle size distribution. It can be estimated that the $\mathrm{Y}_{2} \mathrm{Ti}_{2} \mathrm{O}_{7}$ particles have a mean diameter of $72 \pm 15 \mathrm{~nm}$. The HRTEM image of one typical nanoparticle is illustrated in Fig.1 (c). The interlayer spacing of $0.586 \mathrm{~nm}$ is consistent with the (111) plane of $\mathrm{Y}_{2} \mathrm{Ti}_{2} \mathrm{O}_{7}$, which further confirms the formation of $\mathrm{Y}_{2} \mathrm{Ti}_{2} \mathrm{O}_{7}$ phase. These $\mathrm{Y}_{2} \mathrm{Ti}_{2} \mathrm{O}_{7} \mathrm{NPs}$, as starting material, are subsequently dispersed in the Al-containing ODS steels by MA.

\subsection{Microstructure evolution of $\mathrm{Fe}-20 \mathrm{wt} . \% \mathrm{Y}_{2} \mathrm{Ti}_{2} \mathrm{O}_{7}$ model alloy during MA}

Compared with the complex commercial ODS steels, the $\mathrm{Fe}-20$ wt. $\% \mathrm{Y}_{2} \mathrm{Ti}_{2} \mathrm{O}_{7}$ model alloy contains merely $\mathrm{Fe}$ and $\mathrm{Y}_{2} \mathrm{Ti}_{2} \mathrm{O}_{7}$ which enables an effective investigation of the evolution of oxide during MA process. Fig. 2 shows the SEM images of the model alloy powders milled for 2, 48 and $96 \mathrm{~h}$. In the initial stage of MA for $2 \mathrm{~h}$, the powders generally exhibit a plate-like shape due to the fact that the cold welding

effect is stronger than the fragmentation [33]. The powders have a broad size distribution ranging from 1 to $100 \mu \mathrm{m}$ with an average value of $23 \pm 21 \mu \mathrm{m}$, as shown in Fig. 2(a). After $48 \mathrm{~h}$ of MA, the shape of these particles changes from plate-like into round shape, and the size of the powder is remarkably decreased to an average particle size of $2.8 \pm 1.9 \mu \mathrm{m}$ with a narrow size distribution between 1 and $12 \mu \mathrm{m}$, as shown in Fig. 2(b). The average particle size of the powders milled for $96 \mathrm{~h}$ is $2.3 \pm 1.7$ $\mu \mathrm{m}$, which is almost the same as that of the sample milled for $48 \mathrm{~h}$, as shown in Fig. 2(c).

Fig. 2(d) shows the XRD patterns of the model alloy powders milled for different times. The diffraction peaks from both $\alpha-\mathrm{Fe}$ and $\mathrm{Y}_{2} \mathrm{Ti}_{2} \mathrm{O}_{7}$ are clearly visible after $2 \mathrm{~h}$ milling. In contrast, most of the diffraction peaks of $\mathrm{Y}_{2} \mathrm{Ti}_{2} \mathrm{O}_{7}$ disappear after $48 \mathrm{~h}$ milling, except for a very weak and broad peak around $30^{\circ}$. There is no apparent difference in the XRD patterns of the samples milled for 48 and $96 \mathrm{~h}$. Early studies on 
the behavior of $\mathrm{Y}_{2} \mathrm{O}_{3}$ in ODS steels suggested that $\mathrm{Y}_{2} \mathrm{O}_{3}$ was decomposed and dissolved in the ferrite matrix during MA [34-35]. Recent studies, however, supported the mechanism of the amorphorization or nanocrystalline formation of oxide during MA [31,36-37]. Our work on the Fe-25 wt.\% $\mathrm{Y}_{2} \mathrm{O}_{3}$ model alloy milled for $48 \mathrm{~h}$ indicated that the dissociation and dissolution of $\mathrm{Y}_{2} \mathrm{O}_{3}$ did not take place because the lattice parameters of Fe did not change according to the XRD analysis results [31]. Instead, $\mathrm{Y}_{2} \mathrm{O}_{3}$ became amorphous-like at the grain boundaries of ferrite matrix due to the severe fragmentation of $\mathrm{Y}_{2} \mathrm{O}_{3}$ particles. Dai and coworkers also proved that the Y-O bonds still remained after $100 \mathrm{~h}$ of milling according to the XPS analysis [36]. Phaniraj et al. showed that yttria did not dissolve in the austenite ODS alloys by the XRD and high-resolution TEM analyses [38]. It is found in Fig. 2(d) that the diffraction peaks of $\alpha$-Fe do not shift by the addition of $\mathrm{Y}_{2} \mathrm{Ti}_{2} \mathrm{O}_{7}$ NPs, implying that $\mathrm{Y}_{2} \mathrm{Ti}_{2} \mathrm{O}_{7}$ does not decompose and dissolve in the $\mathrm{Fe}$ matrix during MA. The broadening of diffraction peaks of $\mathrm{Y}_{2} \mathrm{Ti}_{2} \mathrm{O}_{7}$ can be possibly attributed to the amorphorization or the further refinement of crystalline size of $\mathrm{Y}_{2} \mathrm{Ti}_{2} \mathrm{O}_{7}$ clusters. Since $\mathrm{Y}_{2} \mathrm{O}_{3}$ can react with $\mathrm{Ti}$ or $\mathrm{Al}$ to form $\mathrm{Y}-\mathrm{Ti}-\mathrm{O}$ or $\mathrm{Y}-\mathrm{Al}-\mathrm{O}$ complex oxides [5,24], we propose that the complex oxide $\mathrm{Y}_{2} \mathrm{Ti}_{2} \mathrm{O}_{7}$ is more chemically stable than $\mathrm{Y}_{2} \mathrm{O}_{3}$.

To further confirm the chemical bonds of each element in the model alloy sample milled for $96 \mathrm{~h}$, the XPS spectra of $\mathrm{O}(1 \mathrm{~s}), \mathrm{Y}(3 \mathrm{~d}), \mathrm{Ti}(2 \mathrm{p})$ and $\mathrm{Fe}(2 \mathrm{p})$ were measured and shown in Fig. 3. The peak of $\mathrm{O}$ 1s in Fig. 3(a) can be fitted with a strong peak at $529.9 \mathrm{eV}$ and a weak peak at $531.6 \mathrm{eV}$. The strong peak is assigned to metallic oxide, and the weak one can be attributed to hydroxyl groups, chemisorbed oxygen or organic oxygen on the surface of the sample [39-40]. The appearance of $\mathrm{Y} 3 \mathrm{~d}_{5 / 2}$ peak at $157.8 \mathrm{eV}$ and $\mathrm{Y} 3 \mathrm{~d}_{3 / 2}$ peak at $159.7 \mathrm{eV}$ in the XPS spectra of Fig. 3(b) demonstrate that yttrium is in the state of $\mathrm{Y}^{3+}$ in the chemical bond of $\mathrm{Y}_{2} \mathrm{Ti}_{2} \mathrm{O}_{7}$ [40]. Moreover, the 
peaks of $\mathrm{Ti} 2 \mathrm{p}_{3 / 2}$ and $\mathrm{Ti} 2 \mathrm{p}_{1 / 2}$ at 458.1 and $464.0 \mathrm{eV}$ in Fig. 3(c) prove the existence of $\mathrm{Ti}^{4+}$ in $\mathrm{Y}_{2} \mathrm{Ti}_{2} \mathrm{O}_{7}$ [39-40]. The peaks of $\mathrm{Fe}$ at 724.4 and $710.6 \mathrm{eV}$ in Fig. 3(d) indicate that $\mathrm{Fe}$ does not react with other elements to form $\mathrm{Fe}-\mathrm{Y}-\mathrm{O}, \mathrm{Fe}-\mathrm{Ti}-\mathrm{O}$ or $\mathrm{Fe}-\mathrm{O}$ oxides [41]. These results strongly support that $\mathrm{Y}_{2} \mathrm{Ti}_{2} \mathrm{O}_{7}$ is not decomposed and the chemical bond of $\mathrm{Y}_{2} \mathrm{Ti}_{2} \mathrm{O}_{7}$ remains during MA, in good agreement with the XRD results in Fig. 2(d).

To further clarify the structure evolution of $\mathrm{Y}_{2} \mathrm{Ti}_{2} \mathrm{O}_{7}$ during MA, TEM and the selected area electron diffraction (SAED) analyses were conducted. It can be seen from the TEM image in Fig. 4(a) that after $96 \mathrm{~h}$ milling, the size of the particle is decreased to about $300 \mathrm{~nm}$. The SAED analysis was conducted at the edge of the particle, which is in the circle area of "1" in Fig. 4(a), about $100 \mathrm{~nm}$ in thickness. Three rings made of continuous diffraction spots in the SAED pattern of Fig. 4(b) are determined as (110), (200) and (211) planes of $\alpha$-Fe phase, which are illustrated clearly in the sketch map of Fig. 4(c). Considering that the electron beam diameter for the SAED analysis is only about $40 \mathrm{~nm}$, it can be deduced that there are nano-crystallites of $\alpha$-Fe with random crystallographic orientations in the particle. It is worth of noting that a halo ring is also detected near the center spot in Fig. 4(b). By calculating the radius of the halo ring, it can be indexed as $\mathrm{Y}_{2} \mathrm{Ti}_{2} \mathrm{O}_{7}$ phase, which is consistent with the broad peak in the XRD patterns of Fig. 2(d), indicating that the $\mathrm{Y}_{2} \mathrm{Ti}_{2} \mathrm{O}_{7}$ particles are amorphorized after being mechanically alloyed for $96 \mathrm{~h}$. The amorphization of a crystalline material during high energy ball milling usually follows the sequence of ordered phase, fine-grained (nanocrystalline) phase and amorphous phase [42]. In this work, it can be concluded that $\mathrm{Y}_{2} \mathrm{Ti}_{2} \mathrm{O}_{7}$ is not decomposed or dissolved into the Fe matrix, but gradually transforms into amorphous-like status. Fig.S2 in the Supplementary Material shows the TG-DSC 
analysis curves of the model alloy powders milled for $96 \mathrm{~h}$. An obvious exothermic peak near $1018 \mathrm{~K}$ is recognized with a starting temperature of $983 \mathrm{~K}$. We reported previously that the amorphous-like $\mathrm{Y}_{2} \mathrm{O}_{3}$ in the model alloy $\mathrm{Fe}-25$ wt. $\% \mathrm{Y}_{2} \mathrm{O}_{3}$ milled for $48 \mathrm{~h}$ started to crystallize at $873 \mathrm{~K}$ [31]. In this work, the crystallization of $\mathrm{Y}_{2} \mathrm{Ti}_{2} \mathrm{O}_{7}$ in the model alloy $\mathrm{Fe}-20$ wt. $\% \mathrm{Y}_{2} \mathrm{Ti}_{2} \mathrm{O}_{7}$ milled for $96 \mathrm{~h}$ occurs at $983 \mathrm{~K}$. The endothermic peak at $1242 \mathrm{~K}$ in Fig.S2 can be attributed to the phase transition from $\alpha-\mathrm{Fe}$ to $\gamma$-Fe [31]. The amorphous-like $\mathrm{Y}_{2} \mathrm{Ti}_{2} \mathrm{O}_{7} \mathrm{NPs}$ are expected to be converted into the fine oxide dispersoids in the Al-containing ODS steels during the consolidation process.

\subsection{Microstructure of the ODS steels}

Fig. 5 (a)-(c) display the TEM images of the oxide dispersoids in three ODS steels after HIP. All the oxide dispersoids in these ODS steels have nearly spherical or faceted shapes. The histogram in Fig. 5(d) shows that the oxide NPs in Y-0.35 have a size distribution of $1-50 \mathrm{~nm}$, and the mean particle size is $17.1 \pm 11.6 \mathrm{~nm}$, with a number density of $(8.7 \pm 0.9) \times 10^{21} \mathrm{~m}^{-3}$. Similarly, Dou et al. reported that some oxide precipitates up to $30 \mathrm{~nm}$ were also detected in the $\mathrm{Fe}-15.5 \mathrm{Cr}-4 \mathrm{Al}-2 \mathrm{~W}-0.1 \mathrm{Ti}-0.35 \mathrm{Y}_{2} \mathrm{O}_{3}$ wt.\% ODS steels [28]. Surprisingly, the oxide NPs in YT-0.2 have a narrow size distribution of $1-20 \mathrm{~nm}$ and the mean particle size of $8.1 \pm 4.7 \mathrm{~nm}$, with a number density of $(2.6 \pm 0.4) \times 10^{22} \mathrm{~m}^{-3}$, as shown in Fig. 5(e). The number density of the oxide NPs in YT-0.6 increases to $(7.3 \pm 0.6) \times 10^{22} \mathrm{~m}^{-3}$ with the increasing $\mathrm{Y}_{2} \mathrm{Ti}_{2} \mathrm{O}_{7}$ content, whereas the mean particle size $(7.4 \pm 3.7 \mathrm{~nm})$ of the oxide NPs in YT-0.6 is almost same as that in YT-0.2, as shown in Fig. 5(f). Moreover, the majority of the oxide precipitates in YT-0.2 (77.8\%) and YT-0.6 (85.2\%) are within the range of 1-12 $\mathrm{nm}$. Compared with the ODS steel added with $\mathrm{Y}_{2} \mathrm{O}_{3}$, the increasing number densities of nanoprecipitates in YT-0.2 and YT-0.6 are attributed not only to the high stability of 
$\mathrm{Y}_{2} \mathrm{Ti}_{2} \mathrm{O}_{7}$, but also to the high nucleation rate of $\mathrm{Y}_{2} \mathrm{Ti}_{2} \mathrm{O}_{7}$ from a metastable condition, which will be discussed with more details later. The increasing number density of the oxide dispersoids is expected to offer a considerable improvement in the performances of the ODS steels.

HR-TEM technique and fast Fourier transform (FFT) method were further used to identify the crystal structure of individual oxide NPs in different ODS steels. Fig. 6(a) displays a typical oxide particle in Y-0.35, which is of approximately spherical shape with a diameter of $35 \mathrm{~nm}$. The measured interplanar distances are 2.710, 1.985 and 1.620 $\mathrm{A}$, and the measured inter-axial angles are 93.9, 38.0 and 55.9 ${ }^{\circ}$, which are consistent with the (024), (611) and (633) planes of yttrium-aluminum-perovskite (YAP) $\mathrm{YAlO}_{3}$ (JCPDS: 38-0222, Body Centered Cubic). The $\mathrm{YAlO}_{3} \mathrm{NPs}$ were reported to be formed through the reaction between $\mathrm{Y}_{2} \mathrm{O}_{3}$ and $\mathrm{Al}_{2} \mathrm{O}_{3}$ at a temperature between 1373 and $1523 \mathrm{~K}$ [43]. In the present work, the $\mathrm{YAlO}_{3} \mathrm{NPs}$ in Y-0.35 are produced during HIP at $1433 \mathrm{~K}$, whereas the Y-Ti-O complex oxides can not be detected, which is similar to the previous studies on the Al-containing ODS steels [28]. Thus, the relatively large oxides in Y-0.35 should be attributed to the formation of $\mathrm{YAlO}_{3}$ particles. The FFT image in Fig. 6(b), which is generated from Fig. 6(a), clearly illustrates the planes of the matrix and the oxide with the $[1 \overline{4} 2]_{\text {YAlO3 }}$ zone parallel to $[111]_{\mathrm{M}}$. The current lattice fringe pattern and the corresponding FFT image show no lattice coherency between $\mathrm{YAlO}_{3}$ and the matrix, which is in agreement with the studies on other Al-containing ODS steels, such as PM2000 [26].

Fig. 7(a) shows the HR-TEM image of one typical oxide nanoparticle $(5 \mathrm{~nm})$ surrounded by the matrix lattice in YT-0.2, and the corresponding FFT pattern is illustrated in Fig. 7(b). It can be identified that the matrix interplanar distances are 
consistent with the (110) and (200) planes of $\alpha-F e, d_{110}=2.027 \AA$ and $d_{200}=1.433$

A. The interplanar distances of the spherical particle in Fig. 7(a) are 2.564, 2.542 and $1.764 \AA$, and the inter-axial angles are determined as $90.5,44.5$ and $46.0^{\circ}$. These results agree well with the (400), $(0 \overline{4} 0)$ and $(4 \overline{4} 0)$ planes of pyrochlore $\mathrm{Y}_{2} \mathrm{Ti}_{2} \mathrm{O}_{7}$ (JCPDS: 42-0413, Space group: F $d \overline{3} m$ ) of face centered cubic (fcc) structure. This further demonstrates the transition of $\mathrm{Y}_{2} \mathrm{Ti}_{2} \mathrm{O}_{7}$ from amorphous state during $\mathrm{MA}$ to crystalline precipitates during HIP. The FFT image of Fig. 7(b) generated from Fig. 7(a) belongs to the $[001]_{\mathrm{Y} 2 \mathrm{Ti2O} 2}$ zone, which is parallel to $[001]_{\mathrm{M}}$. Thus, there is a close crystallographic match between the fcc- $\mathrm{Y}_{2} \mathrm{Ti}_{2} \mathrm{O}_{7}$ particle and the bcc-ferrite matrix with the orientation relationship of $[001]_{\mathrm{Y} 2 \mathrm{Ti} 2 \mathrm{O} 7} / /[001]_{\mathrm{M}},(400)_{\mathrm{Y} 2 \mathrm{Ti2O}} / /(110)_{\mathrm{M}}$ and $(440)_{\mathrm{Y} 2 \mathrm{Ti} 2 \mathrm{O} 7} / /(020)_{\mathrm{M}}$. For the ODS ferritic steel of Fe-14Cr-1W-0.3Ti-0.3 $\mathrm{Y}_{2} \mathrm{O}_{3}$, Ribis [44] found that the orientation relationship of $\mathrm{Y}_{2} \mathrm{Ti}_{2} \mathrm{O}_{7}$ oxide and the matrix is $(100)_{\mathrm{M}} / /(100)_{\mathrm{Y} 2 \mathrm{Ti2O}}$ and $[100]_{\mathrm{M}} / /[100]_{\mathrm{Y} 2 \mathrm{Ti2O}}$. This indicates that the orientation relationship between pyrochlore-type $\mathrm{Y}_{2} \mathrm{Ti}_{2} \mathrm{O}_{7}$ nanoprecipitates and the matrix can vary for different ODS steels.

For a coherent interface with misfit, the $D_{\text {misfit }}$, which stands for the distance of eventual periodical misfit dislocations generated by overlap of two gratings $d_{1}$ and $d_{2}$, can be calculated by the following equation [45]:

$$
\mathrm{D}_{\text {misfit }}=\left(d_{2}+d_{1}\right) / 2 \varepsilon^{*}
$$

where $\varepsilon^{*}$ is the lattice misfit and can be expressed as:

$$
\varepsilon^{*}=2\left(d_{2}-d_{1}\right) /\left(d_{2}+d_{1}\right)
$$

Ribis et al. [44] found that $\mathrm{Y}_{2} \mathrm{Ti}_{2} \mathrm{O}_{7}$ nanoprecipitates in the ferritic ODS steel without $\mathrm{Al}$ addition were semi-coherent with the matrix, and the interplanar crystal spacing relationship was $8 \mathrm{~d}(110)_{\mathrm{M}}=9 \mathrm{~d}(440)_{\mathrm{Y} 2 \mathrm{Ti2O}}$. Ramar also claimed that the dispersed 
Y-Ti-O nanoprecipitates were partially coherent with the matrix of EUROFER97 alloy [17]. But the orientation relationship was not provided. In this work, according to equation (2), the lattice misfit $\varepsilon^{*}$ between $\mathrm{Y}_{2} \mathrm{Ti}_{2} \mathrm{O}_{7}$ and the matrix corresponding to $\mathrm{d}_{1}=\mathrm{d}(110)_{\alpha-\mathrm{Fe}}=2.027 \AA$ and $\mathrm{d}_{2}=\mathrm{d}(400)_{\mathrm{Y} 2 \mathrm{Ti} 2 \mathrm{O} 7}=2.523 \AA$ in $\mathrm{YT}-0.2$ can be calculated to be $21.8 \%$. For $\mathrm{d}_{1}=\mathrm{d}(200)_{\mathrm{M}}=1.433 \AA$ and $\mathrm{d}_{2}=\mathrm{d}(440)_{\mathrm{Y} 2 \mathrm{Ti} 2 \mathrm{O} 7}=1.784$ A, the same lattice misfit of $21.8 \%$ is obtained. The misfit values suggest that the fcc- $\mathrm{Y}_{2} \mathrm{Ti}_{2} \mathrm{O}_{7}$ NPs are semi-coherent with the bcc matrix. The distances $D_{\text {misfit }}$ between misfit dislocations calculated by equation (1) are 1.04 and $0.74 \mathrm{~nm}$ for these two orientations. They correspond to $5 \mathrm{~d}(110)_{\mathrm{M}}=4 \mathrm{~d}(400)_{\mathrm{Y} 2 \mathrm{Ti2O}}=1.01 \mathrm{~nm}$ and $5 \mathrm{~d}(200)_{\mathrm{M}}=$ $4 \mathrm{~d}(440)_{\mathrm{Y} 2 \mathrm{Ti} 2 \mathrm{O} 7}=0.71 \mathrm{~nm}$. Fig. 8 schematically illustrates one $\mathrm{Y}_{2} \mathrm{Ti}_{2} \mathrm{O}_{7}$ nanoparticle embedded in the matrix according to the periodical misfit distance, which clearly displays the semi-coherency between $\mathrm{Y}_{2} \mathrm{Ti}_{2} \mathrm{O}_{7}$ and the matrix. The formation mechanism of $\mathrm{Y}_{2} \mathrm{Ti}_{2} \mathrm{O}_{7}$ NPs through amorphization and crystallization in this work is different from that of the Y-Ti-O oxides formed in the conventional ODS steels by means of the combination of $\mathrm{Ti}$ and $\mathrm{Y}_{2} \mathrm{O}_{3}$ during $\mathrm{MA}$ and consolidation processes $[12,15,17]$. As a result, the interface relationship between $\mathrm{Y}_{2} \mathrm{Ti}_{2} \mathrm{O}_{7}$ and the matrix in our alloys is different from the conventional ODS steels.

Fig. 9(a) and (b) display the HR-TEM lattice images of two oxide NPs of $6 \mathrm{~nm}$ and $11 \mathrm{~nm}$ surrounded by the matrix in YT-0.6. According to the measured interplanar distances and the inter-axial angles, both the larger $(11 \mathrm{~nm})$ and the smaller $(6 \mathrm{~nm})$ oxide NPs are indexed to be fcc- $\mathrm{Y}_{2} \mathrm{Ti}_{2} \mathrm{O}_{7}$. The FFT images of Fig. 9(c) and (d) are generated from Fig. 9(a) and (b), respectively, with the [001] $]_{\text {Y2Ti2O7 }}$ zone parallel to $[001]_{\mathrm{M}}$. These two NPs have exhibited the same orientation relationships with the matrix in two directions, $(400)_{\mathrm{Y} 2 \mathrm{Ti2O}} / /(110)_{\mathrm{M}}$ and $(440)_{\mathrm{Y} 2 \mathrm{Ti2O}} / /(020)_{\mathrm{M}}$, 
similar to the result of YT-0.2. The calculated lattice misfit values $(21.8 \%)$ in two directions are identical, implying a semi-coherent interface between $\mathrm{Y}_{2} \mathrm{Ti}_{2} \mathrm{O}_{7}$ and the matrix. TEM observations of several tens of oxide NPs in the ODS steels (YT-0.2 and YT-0.6) added with $\mathrm{Y}_{2} \mathrm{Ti}_{2} \mathrm{O}_{7}$ confirm that all the oxide dispersoids are pyrochlore $\mathrm{Y}_{2} \mathrm{Ti}_{2} \mathrm{O}_{7}$ with a semi-coherent interface with the ferritic matrix after HIP. It has been reported that the coherency of the oxide with the matrix depends on its size $[12,28]$. In this work, however, both the large and small oxide NPs in YT-0.2 and YT-0.6 display a semi-coherent interface with the matrix. It can be concluded that the $\mathrm{Y}_{2} \mathrm{Ti}_{2} \mathrm{O}_{7} \mathrm{NPs}$ directly added in the Al-containing ODS steels are so stable that no Y-Al-O complex oxides can be created during MA and HIP, which is different from the conventional Al-containing ODS steels added with $\mathrm{Y}_{2} \mathrm{O}_{3}$ NPs $[24,46]$. In addition, it should be noted that the semi-coherent interface between the $\mathrm{Y}_{2} \mathrm{Ti}_{2} \mathrm{O}_{7} \mathrm{NPs}$ and the ferrite matrix plays the dominant role in refining the oxide during the consolidation at high temperature. The interface energy between the oxide NPs and the ferrite matrix can be greatly reduced when a semi-coherent interface is formed [47]. In this work, the formation of stable oxide dispersoids in the metal matrix is supposed to start from the nucleation and crystallization of the amorphous-like oxides during consolidation. Low interface energy results in low nucleation barrier, and consequently the nucleation rate is greatly improved and the coarsening kinetics is reduced [48]. It can be deduced that the metastable $\mathrm{Y}_{2} \mathrm{Ti}_{2} \mathrm{O}_{7}$ clusters created in the matrix during MA preferentially nucleate on the (110) or (200) planes of the ferrite matrix and grow into the fcc- $\mathrm{Y}_{2} \mathrm{Ti}_{2} \mathrm{O}_{7} \mathrm{NPs}$.

\subsection{Mechanical properties of the ODS steels}

Fig. 10 shows the tensile strain-stress curves of three ODS steels at $298 \mathrm{~K}$, and Table 2 summarizes the results of ultimate tensile strength, yield strength and uniform 
elongation of Y-0.35, YT-0.2 and YT-0.6. It is found that compared with Y-0.35 added with $\mathrm{Y}_{2} \mathrm{O}_{3}$ NPs, the tensile strength of the ODS steel increases remarkably with the addition of $\mathrm{Y}_{2} \mathrm{Ti}_{2} \mathrm{O}_{7}$ NPs. The average ultimate tensile strengths of YT-0.2, YT-0.6 and Y-0.35 are 1238, 1296 and $949 \mathrm{MPa}$, and the average yield strengths are 993, 1013 and $687 \mathrm{MPa}$, respectively. The ultimate tensile strength of YT-0.6 is $347 \mathrm{MPa}$ higher than that of Y-0.35. Klueh et al. [49] reported that the tensile strength ( $900 \mathrm{MPa})$ of the Al-containing ODS steel (PM2000) is much lower than that $(\sim 1300 \mathrm{MPa})$ of the Al free ODS steels (12YWT and MA957). However, the present study shows that the tensile strengths of the Al-containing ODS steels can be tuned to approach those of the $\mathrm{Al}$ free ODS steels (12YWT and MA957) by adding $\mathrm{Y}_{2} \mathrm{Ti}_{2} \mathrm{O}_{7}$ NPs as starting oxide powder during MA. The strength of ODS steels is determined by three factors, dispersion strengthening (Orowan strengthening), grain boundary (Hall-Petch) strengthening and ordered matrix strengthening [50]. The matrix compositions of three ODS steels (Y-0.35, YT-0.2, and YT-0.6) in this work are same. Moreover, there is no apparent difference in grain sizes for these ODS steels (see Fig.S3 in the Supplementary Material), and all of them have grains of 0.6-1.8 $\mu \mathrm{m}$ with an average of about $1.2 \mu \mathrm{m}$. Thus, the difference in strength of these ODS steels is mainly caused by Orowan strengthening of the oxide dispersoids. The strength attributed to Orowan strengthening, $\sigma_{\mathrm{OR}}$, can be expressed by the following equation [51-52]:

$$
\sigma_{O R}=\frac{2 m \mu b}{4 \pi \times(1.18) \times(\lambda-\phi)} \ln \left(\frac{\phi}{2 b}\right)
$$

where $\phi$ is the particle size and $\lambda$ the particle separation deduced using the volume fraction of fine particles, $m$ the Taylor factor, $\mu$ the shear modulus, and $b$ the Burgers vector. According to the particle-dislocation interaction theory, for a given volume fraction of oxide dispersoids, the smaller the inter-particle distance $\lambda$, the higher the ultimate strength of the ODS steels. With the addition of $\mathrm{Y}_{2} \mathrm{Ti}_{2} \mathrm{O}_{7}$, the mean sizes of 
the oxide dispersoids in YT-0.2 and YT-0.6 decrease remarkably, and their number densities reach $(2.6 \pm 0.4) \times 10^{22} \mathrm{~m}^{-3}$ and $(7.3 \pm 0.6) \times 10^{22} \mathrm{~m}^{-3}$, respectively, which are one order of magnitude higher than that of $\mathrm{Y}-0.35,(8.7 \pm 0.9) \times 10^{21} \mathrm{~m}^{-3}$. Thus, compared with Y-0.35, the distances between the neighboring oxide dispersoids YT-0.2 and YT-0.6 are greatly reduced, resulting in stronger barrier for the movement of dislocation. Moreover, the critical shear stress strongly depends on the coherency between particles and surrounding matrix [45]. A full coherency or semi-coherency can effectively increase the shear modulus and further improve the Orowan strengthening effect. In this work, the semi-coherent interface between the $\mathrm{Y}_{2} \mathrm{Ti}_{2} \mathrm{O}_{7}$ NPs and the matrix is supposed to efficiently prohibit the movement of dislocation near these oxide NPs as well. More interestingly, Fig. 10 shows that both YT-0.2 and YT-0.6 exhibit good plastic deformation capabilities. The average uniform elongation of YT-0.2 and YT-0.6 is 12.7 and $11.6 \%$, respectively, which is higher than that of Y-0.35 (10.9\%). With the increasing $\mathrm{Y}_{2} \mathrm{Ti}_{2} \mathrm{O}_{7}$ content, the uniform elongation of YT-0.6 is only slightly lower than that of YT-0.2. All the tensile fracture morphologies of these ODS steels display typical ductile fracture features with dimples of about 1 $\mu \mathrm{m}$ in diameter, see Fig.S4 in the Supplementary Material. It can be concluded that the addition of the $\mathrm{Y}_{2} \mathrm{Ti}_{2} \mathrm{O}_{7} \mathrm{NPs}$ as starting powder to substitute the conventional $\mathrm{Y}_{2} \mathrm{O}_{3}$ NPs can substantially improve the strength of the Al-containing ODS steels. This provides a new way to develop the high performance ODS steels with both high mechanical strength and good corrosion resistance.

\section{Conclusions}

$\mathrm{Y}_{2} \mathrm{Ti}_{2} \mathrm{O}_{7}$ NPs with size of $72 \pm 15 \mathrm{~nm}$ were successfully prepared by annealing Y-Ti hydrides NPs at $1173 \mathrm{~K}$ for $1 \mathrm{~h}$, and then were added as starting powder to produce the Al-containing ODS steels. The $\mathrm{Y}_{2} \mathrm{Ti}_{2} \mathrm{O}_{7} \mathrm{NPs}$ were not decomposed, but 
transformed into amorphous-like clusters during MA. Compared with the relatively large Y-Al-O NPs with the size of 5-100 $\mathrm{nm}$ in the conventional ODS steels added with $\mathrm{Y}_{2} \mathrm{O}_{3}$, the $\mathrm{Y}_{2} \mathrm{Ti}_{2} \mathrm{O}_{7}$ NPs in the ODS steel added with 0.6 wt. $\% \mathrm{Y}_{2} \mathrm{Ti}_{2} \mathrm{O}_{7}$ possessed a smaller average size of $7.4 \pm 3.7 \mathrm{~nm}$ and a larger number density of $(7.3 \pm 0.6) \times 10^{22}$ $\mathrm{m}^{-3}$ after $\mathrm{HIP}$ at $1433 \mathrm{~K}$. Moreover, the $\mathrm{Y}_{2} \mathrm{Ti}_{2} \mathrm{O}_{7}$ NPs shared the semi-coherent interface with the ferrite matrix, (400) ${ }_{\mathrm{Y} 2 \mathrm{Ti2O}} / /(110)_{\mathrm{M}}$ and $(440)_{\mathrm{Y} 2 \mathrm{Ti2O}} / /(020)_{\mathrm{M}}$ oriented along the $[001]_{\mathrm{Y} 2 \mathrm{Ti} 2 \mathrm{O} 7} / /[001]_{\mathrm{M}}$ zone axis. The tensile strength and uniform elongation of the ODS steels added with 0.2 and 0.6 wt. $\% \mathrm{Y}_{2} \mathrm{Ti}_{2} \mathrm{O}_{7}$ were better than those of the ODS steel added with 0.35 wt. $\% \mathrm{Y}_{2} \mathrm{O}_{3}$. Our work demonstrates a novel route to fabricate high performance ODS steels with both high mechanical strength and good corrosion resistance.

\section{Acknowledgments}

The authors acknowledge the support of this work by the Joint Funds of the National Natural Science Foundation of China (No. U1560106), the Aeronautical Science Foundation of China (No. 2014ZF51069), and the Scientific Research Foundation for the Returned Overseas Chinese Scholars, State Education Ministry.

\section{References}

[1] J. Zhang, Lead-Bismuth Eutectic (LBE): A Coolant Candidate for Gen. IV Advanced Nuclear Reactor Concepts, Adv. Eng. Mater. 16 (2014) 349.

[2] P. Hosemann, H.T. Thau, A.L. Johnson, S.A. Maloy, N. Li, Corrosion of ODS steels in lead-bismuth eutectic, J. Nucl. Mater. 373 (2008) 246.

[3] H.L. Lu, Y. Ishiwatari, Y. Oka, Study on the LLFPs transmutation in a super-critical water-cooled fast reactor, Nucl. Eng. Des. 241 (2011) 395.

[4] J. Isselin, R. Kasada, A Kimura, Corrosion behaviour of $16 \% \mathrm{Cr}-4 \% \mathrm{Al}$ and $16 \% \mathrm{Cr}$ ODS ferritic steels under different metallurgical conditions in a supercritical water 
environment, Corros. Sci. 52 (2010) 3266.

[5] Y.P. Xia, X.P. Wang, Z. Zhuang, Q.X. Sun, T. Zhang, Q.F. Fang, T. Hao, C.S. Liu, Microstructure and oxidation properties of 16Cr-5Al-ODS steel prepared by sol-gel and spark plasma sintering methods, J. Nucl. Mater. 432 (2013) 198.

[6] J. Chao, C. Capdevila, M. Serrano, A. Garcia-Junceda, J.A. Jimenez, M.K. Miller, Effect of $\alpha-\alpha^{\prime}$ phase separation on notch impact behavior of oxide dispersion strengthened (ODS) Fe20Cr5Al alloy, Mater. Des. 53 (2014) 1037.

[7] T. Liu, C.X. Wang, H.L. Shen, W.S. Chou, A. Kimura, The effects of Cr and Al concentrations on the oxidation behavior of oxide dispersion strengthened ferritic alloys, Corros. Sci. 76 (2013) 310.

[8] B.A. Pint, S. Dryepondt, K.A. Unocic, D.T. Hoelzer, Development of ODS FeCrAl for Compatibility in Fusion and Fission Energy Applications, JOM. 66 (2014) 2458.

[9] M. Yurechko, C. Schroer, O. Wedemeyer, A. Skrypnik, J. Konys, Creep-rupture tests on chromium-containing conventional and ODS steels in oxygen-controlled $\mathrm{Pb}$ and air at $650{ }^{\circ} \mathrm{C}$, Nucl. Eng. Des. 280 (2014) 686.

[10] V.V. Sagaradze, V.I. Shalaev, V.L. Arbuzov, B.N. Goshchitskii, T. Yun, Q. Wan, J.G. Sun, Radiation resistance and thermal creep of ODS ferritic steels, J. Nucl. Mater. 295 (2001) 265.

[11] V. de Castro, E.A. Marquis, S. Lozano-Perez, R. Pareja, M.L. Jenkins, Stability of nanoscale secondary phases in an oxide dispersion strengthened $\mathrm{Fe}-12 \mathrm{Cr}$ alloy, Acta mater. 59 (2011) 3927.

[12] A. Hirata, T. Fujita, Y.P. Wen, J.H. Schneibel, C.T. Liu, M.W. Chen, Atomic structure of nanoclusters in oxide-dispersion-strengthened steels, Nat. Mater. 10 (2011) 922. 
[13] R. Vijay, M. Nagini, S.S. Sarma, M. Ramakrishna, A.V. Reddy, G. Sundararajan, Structure and Properties of Nano-Scale Oxide-Dispersed Iron, Metall. Mater. Trans. A. 45 (2014) 777.

[14] H. Sakasegawa, L. Chaffron, F. Legendre, L. Boulanger, T. Cozzika, M. Brocq, Y. de Carlan, Correlation between chemical composition and size of very small oxide particles in the MA957 ODS ferritic alloy, J. Nucl. Mater. 384 (2009) 115.

[15] S. Yamashita, S. Ohtsuka, N. Akasaka, S. Ukai, S. Ohnukiy, Formation of nanoscale complex oxide particles in mechanically alloyed ferritic steel, Phil. Mag. Lett. 84 (2004) 525.

[16] M. Brocq, B. Radiguet, S. Poissonnet, F. Cuvilly, P. Pareige, F. Legendre, Nanoscale characterization and formation mechanism of nanoclusters in an ODS steel elaborated by reactive-inspired ball-milling and annealing, J. Nucl. Mater. 409 (2011) 80.

[17] A. Ramar, N. Baluc, R. Schablin, On the lattice coherency of oxide particles dispersed in EUROFER97, J. Nucl. Mater. 386-388 (2009) 515.

[18] Y.R. Wen, Y. Liu, A. Hirata, F. Liu, T. Fujita, Y.H. Dou, D.H. Liu, B. Liu, Z.M. Liu, C.T. Liu, Innovative processing of high-strength and low-cost ferritic steels strengthened by Y-Ti-O nanoclusters, Mater. Sci. Eng. A. 544 (2012) 59.

[19] S. Takaya, T. Furukawa, K. Aoto, G. Muller, A. Weisenburger, A. Heinzel, M. Inoue, T. Okuda, F. Abe, S. Ohnuki, T. Fujisawa, A. Kimura, Corrosion behavior of Al-alloying high Cr-ODS steels in lead-bismuth eutectic, J. Nucl. Mater. 386 (2009) 507.

[20] S. Takaya, T. Furukawa, M. Inoue, T. Fujisawa, T. Okuda, F. Abe, S. Ohnuki, A. Kimura, Corrosion resistance of Al-alloying high Cr-ODS steels in stagnant lead-bismuth, J. Nucl. Mater. 398 (2010) 132. 
[21] H.S. Cho, A. Kimura, S. Ukai, M. Fujiwara, Corrosion properties of oxide dispersion strengthened steels in super-critical water environment, J. Nucl. Mater. 329-333 (2004) 387.

[22] A. Kimura, R. Kasada, N. Iwata, H. Kishimoto, C.H. Zhang, J. Isselin, P. Dou, J.H. Lee, N. Muthukumar, T. Okuda, M. Inoue, S. Ukai, S. Ohnuki, T. Fujisawa, T.F. Abe, Development of Al added high-Cr ODS steels for fuel cladding of next generation nuclear systems, J. Nucl. Mater. 417 (2011) 176.

[23] J.H. Lee, R. Kasada, A. Kimura, T. Okuda, M. Inoue, S. Ukai, S. Ohnuki, T. Fujisawa, F. Abe, Influence of alloy composition and temperature on corrosion behavior of ODS ferritic steels, J. Nucl. Mater. 417 (2011) 1225.

[24] R. Kasada, N. Toda, K. Yutani, H.S. Cho, H. Kishimoto, A. Kimura, Pre- and post-deformation microstructures of oxide dispersion strengthened ferritic steels, J. Nucl. Mater. 367-370 (2007) 222.

[25] L.L. Hsiung, M.J. Fluss, S.J. Tumey, B.W. Choi, Y. Serruys, F. Willaime, A. Kimura, Formation mechanism and the role of nanoparticles in Fe-Cr ODS steels developed for radiation tolerance, Phys. Rev. B. 82 (2010) 184103.

[26] Z.B. Zhang. Interface and orientation relationship between oxide nanoparticles and ferrite. In: Nanostructures in a ferritic and an oxide dispersion strengthened steel induced by dynamic plastic deformation, DTU Wind Energy PhD-0045 (EN); 2015, p. 116.

[27] Maruzen. Metal Data Book. The Japan Institute of Metals; 1984, pp. 84.

[28] P. Dou, A. Kimura, T. Okuda, M. Inoue, S. Ukai, S. Ohnuki, T. Fujisawa, F. Abe, Polymorphic and coherency transition of Y-Al complex oxide particles with extrusion temperature in an Al-alloyed high-Cr oxide dispersion strengthened ferritic steel, Acta Mater. 59 (2011) 992. 
[29] T. Liu, C.X. Wang, H.L. Shen, Y.R. Cao, Influence of $\mathrm{YH}_{2}$ Nanoparticles Addition on the Microstructure and Mechanical Properties of Oxide Dispersion Strengthened Ferritic Alloys, Adv. Eng. Mater. 17 (2015) 689.

[30] T. Liu, T.W. Zhang, M. Zhu, C.G. Qin, Synthesis and structures of Al-Ti nanoparticles by hydrogen plasma-metal reaction, J. Nanopart. Res. 14 (2012) 738.

[31] T. Liu, H.L. Shen, C.X. Wang, W.S. Chou, Structure evolution of $\mathrm{Y}_{2} \mathrm{O}_{3}$ nanoparticle/Fe composite during mechanical milling and annealing, Prog. Nat. Sci. $23(2013) 434$.

[32] M.P. van Dijk, J.H.H. ter Maat, G. Roelofs, H. Bosch, G.M.H. van de Velde, P.J. Gellings, A.J. Burggraaf, Electrical and catalytic properties of some oxides with the fluorite or pyrochlore structure: Part 1: Synthesis, characterization and conductivity, Mater. Res. Bull. 19 (1984) 1149.

[33] R. Sundaresan, F.H. Froes, Mechanical alloying, JOM. 39 (1987) 22.

[34] T. Okuda, M. Fujiwara, Dispersion behaviour of oxide particles in mechanically alloyed ODS steel, J. Mater. Sci. Lett. 14 (1995) 1600.

[35] S. Ukai, K. Hatakeyama, S. Mizuta, M.Fujiwara, T. Okuda, Perspective of ODS alloys application in nuclear environments, J. Nucl. Mater. 307-311 (2002) 749.

[36] L. Dai, Y.C. Liu, Z.Z. Dong, Size and structure evolution of yttria in ODS ferritic alloy powder during mechanical milling and subsequent annealing, Powder Technol. 217 (2012) 281.

[37] M. Brocq, B. Radiguet, J.-M. Le Breton, F. Cuvilly, P. Pareige, F. Legendre, Nanoscale characterisation and clustering mechanism in an $\mathrm{Fe}-\mathrm{Y}_{2} \mathrm{O}_{3}$ model ODS alloy processed by reactive ball milling and annealing, Acta Mater. 58 (2010) 1806.

[38] M.P. Phaniraj, Dong-Ik Kim, Jae-Hyeok Shim, Y.W. Cho, Microstructure development in mechanically alloyed yttria dispersed austenitic steels, Acta Mater. 57 
(2009) 1856.

[39] V.G. Bessergenev, R.J.F. Pereira, M.C. Mateus, I.V. Khmelinskii, D.A. Vasconcelos, R. Nicula, E. Burkela, A.M. Botelho do Rego, A.I. Saprykin, Study of physical and photocatalytic properties of titanium dioxide thin films prepared from complex precursors by chemical vapour deposition, Thin. Solid. Films. 503 (2006) 29. [40] W. Kallel, S. Bouattour, L.F. Vieira Ferreira, A.M. Botelho do Rego, Synthesis, XPS and luminescence (investigations) of $\mathrm{Li}+$ and/or Y3+ doped nanosized titanium oxide, Mater. Chem. Phys. 114 (2009) 304.

[41] P.C.J. Graat, M.A.J. Somers, Simultaneous determination of composition and thickness of thin iron-oxide films from XPS Fe 2p spectra, Appl. Surf. Sci. 100/101 (1996) 36.

[42] C. Suryanarayana, E. Ivanov, V.V. Boldyrev, The science and technology of mechanical alloying, Mater. Sci. Eng. A 304-306 (2001) 151.

[43] L. Wen, X.D. Sun, Z.M. Xiu, S.W. Chen, C.T. Tsai, Synthesis of nanocrystalline yttria powder and fabrication of transparent YAG ceramics, J. Eur. Ceram. Soc. 24 (2004) 2681.

[44] J. Ribis, Y.D. Carlan, Interfacial strained structure and orientation relationships of the nanosized oxide particles deduced from elasticity-driven morphology in oxide dispersion strengthened materials, Acta Mater. 60 (2012) 238.

[45] J.M. Howe, Interfaces in materials, atomic structure, thermodynamics and kinetics of solid-vapor, solid-liquid and solid-solid interfaces. Chichester: Wiley; 1997.

[46] M.F. Hupalo, M. Terada, A.M. Kliauga, A.F. Padilha, Microstructural characterization of INCOLOY alloy MA 956, Materialwiss. Werkst. 34 (2003) 505.

[47] C. Zener, Theory of Growth of Spherical Precipitates from Solid Solution, J. 
Appl. Phys. 20 (1949) 950.

[48] J. Ribis, M.-L. Lescoat, S.Y. Zhong, M.-H. Mathon, Y. de Carlan, Influence of the low interfacial density energy on the coarsening resistivity of the nano-oxide particles in Ti-added ODS material, J. Nucl. Mater. 442 (2013) S101.

[49] R.L. Klueh, J.P. Shingledecker, R.W. Swindeman, D.T. Hoelzer, Oxide dispersion-strengthened steels: A comparison of some commercial and experimental alloys, J. Nucl. Mater. 341 (2005) 103.

[50] D.G. Morris, M.A. Muñoz-Morris, Nanoprecipitation of oxide particles and related high strength in oxide-dispersion-strengthened iron-aluminium-chromium intermetallics, Acta Mater. 61 (2013) 4636.

[51] M.A. Muñoz-Morris, C. Garcia Oca, D.G. Morris, An analysis of strengthening mechanisms in a mechanically alloyed, oxide dispersion strengthened iron aluminide intermetallic, Acta Mater. 50 (2002) 2825.

[52] M.A. Muñoz-Morris, C. Garcia Oca, D.G. Morris, Microstructure and room temperature strength of $\mathrm{Fe}-40 \mathrm{Al}$ containing nanocrystalline oxide particles, Acta Mater. 51 (2003) 5187. 


\section{Figure Captions}

Fig. 1 (a) XRD pattern, (b) TEM image and particle size distribution, and (c) HR-TEM image of the Y-Ti hydrides NPs annealed at $1173 \mathrm{~K}$ in air for $1 \mathrm{~h}$.

Fig. 2 SEM images of the model alloy powders milled for (a) 2 h, (b) 48 h, (c) 96 h; and (d) XRD patterns of the model alloy powders milled for 2, 48 and $96 \mathrm{~h}$.

Fig. 3 XPS of spectrum of the model alloy sample milled for $96 \mathrm{~h}$ : (a) $\mathrm{O}(1 \mathrm{~s})$, (b) $Y(3 d),(c) \operatorname{Ti}(2 p)$, and (d) $F e(2 p)$

Fig.4 TEM bright field image (a), SAED pattern (b) and sketch map of SAED pattern (c) of one typical particle of the model alloy sample milled for $96 \mathrm{~h}$.

Fig. 5 TEM bright field images of the oxide particles dispersed in the matrix of (a) Y-0.35, (b) YT-0.2 and (c) YT-0.6, and the related histograms of particle size distribution of (d) Y-0.35, (e) YT-0.2 and (f) YT-0.6.

Fig. 6 HR-TEM image of one typical oxide nanoparticle in Y-0.35 (a), and the corresponding FFT image (b).

Fig. 7 HR-TEM image of one typical oxide nanoparticle in YT-0.2 (a), and the corresponding FFT pattern (b).

Fig. 8 Schematic illustration of one $\mathrm{Y}_{2} \mathrm{Ti}_{2} \mathrm{O}_{7}$ oxide nanoparticle embedded semi-coherently in the ferrite matrix.

Fig. 9 HR-TEM images of two typical oxide NPs in YT-0.6 (a) and (b); the corresponding FFT patterns are shown in (c) and (d).

Fig. 10 Tensile strain-stress curves of three ODS steel samples. 

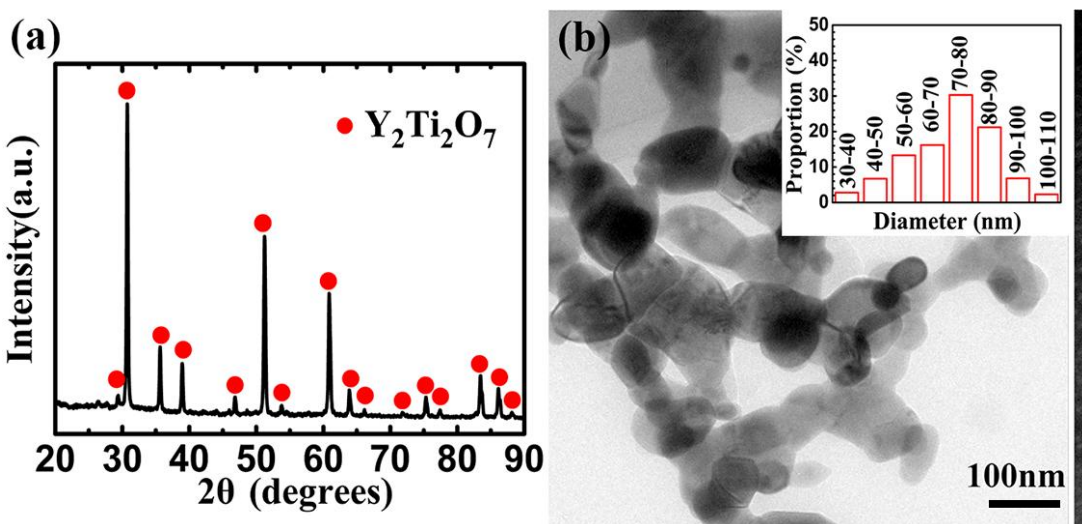

(c)

$0.586 \mathrm{~nm}$

$\mathrm{Y}_{2} \mathrm{Ti}_{2} \mathrm{O}_{7}(111)$

Fig. 1 

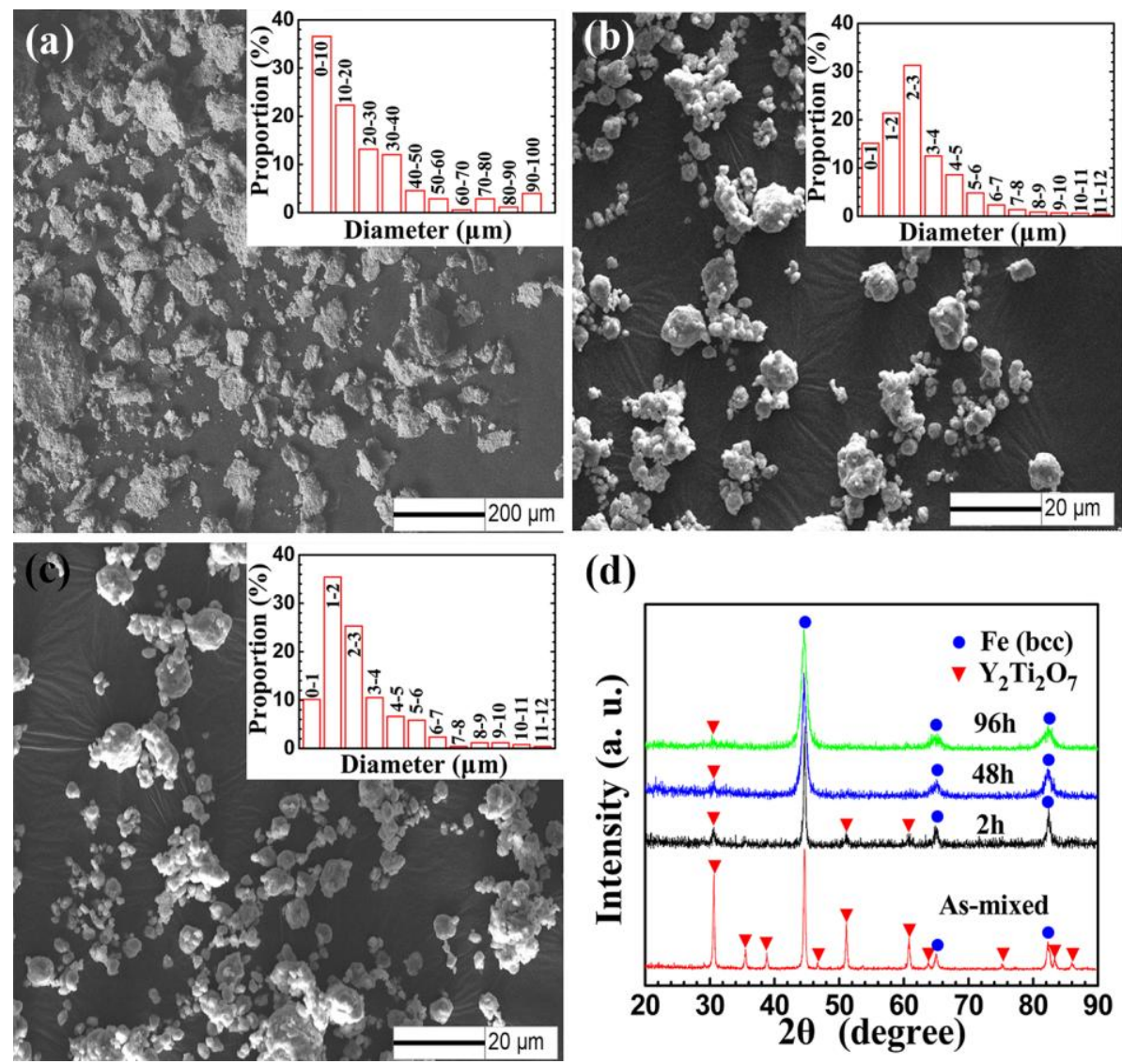

Fig. 2 

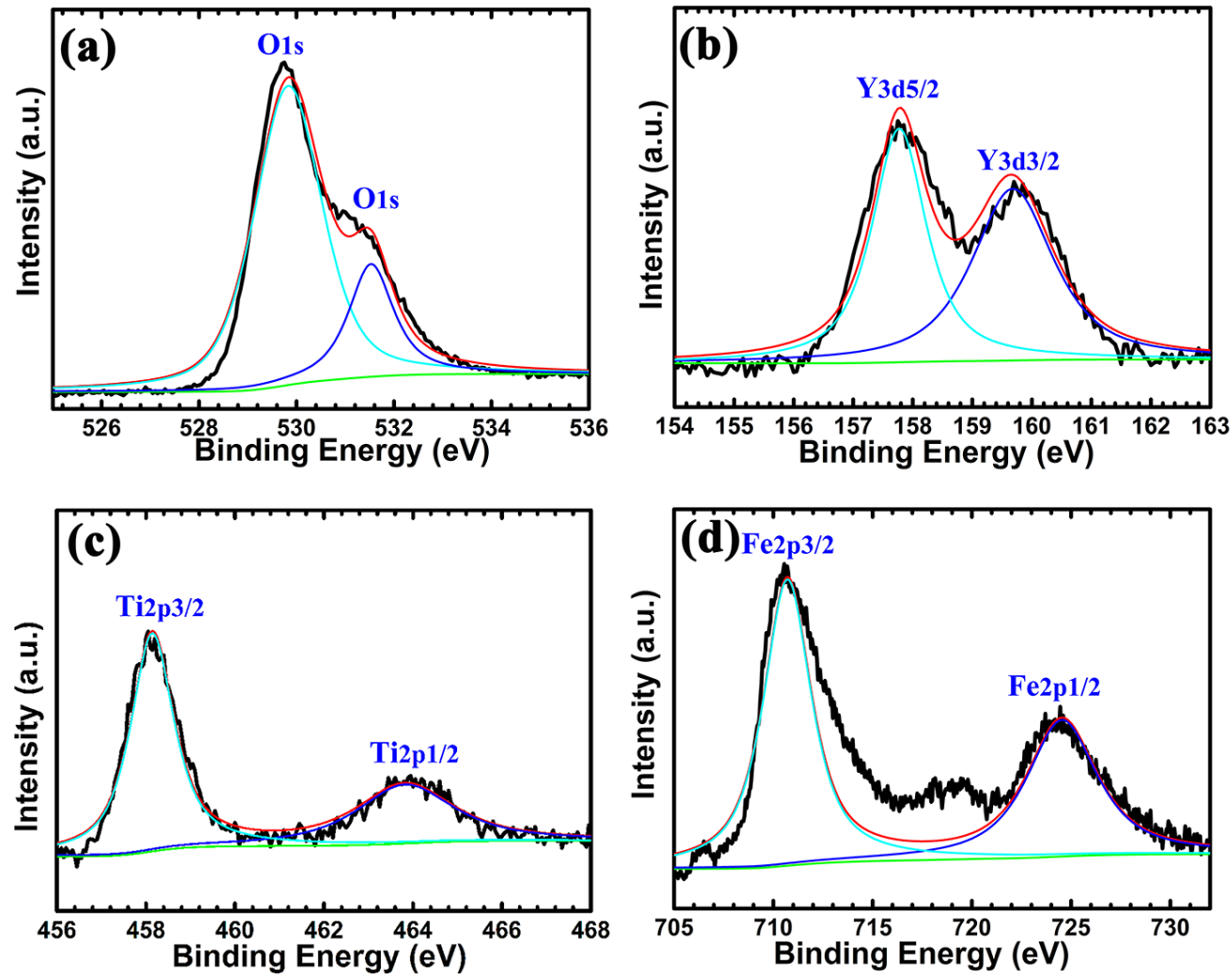

Fig. 3 


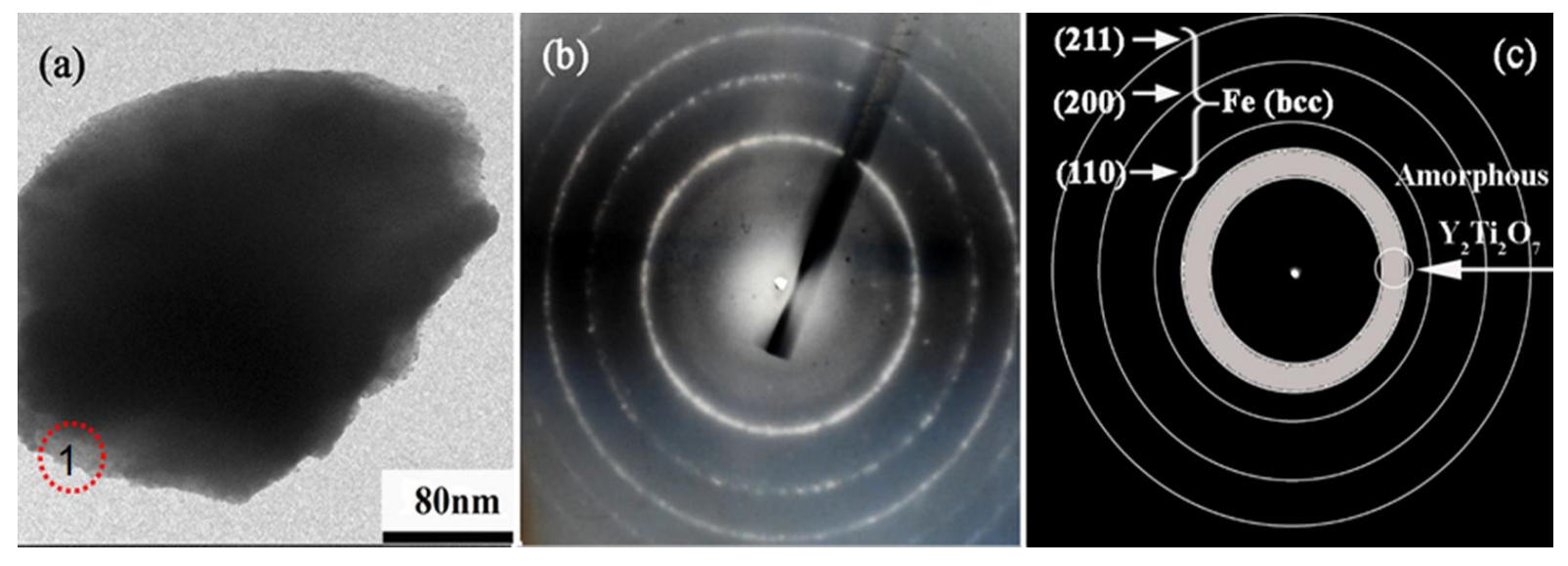

Fig. 4 


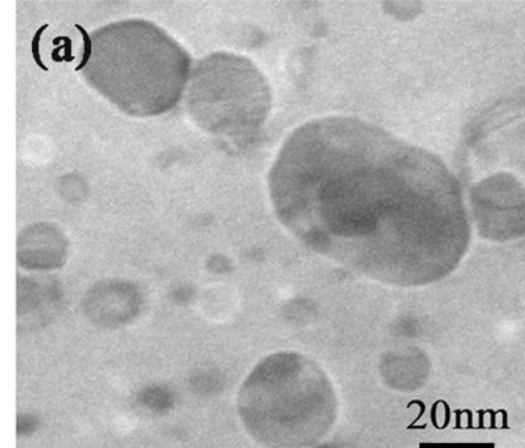

(b)

(c)

(d)

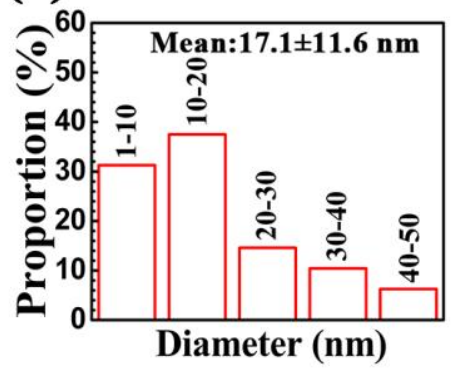

(e)

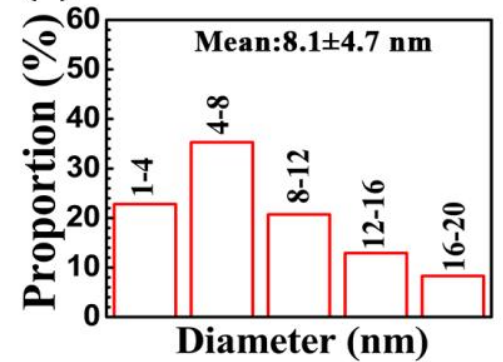

$20 \mathrm{~nm}$

(f)

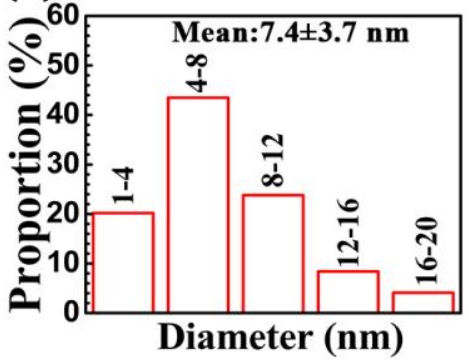

Fig. 5 

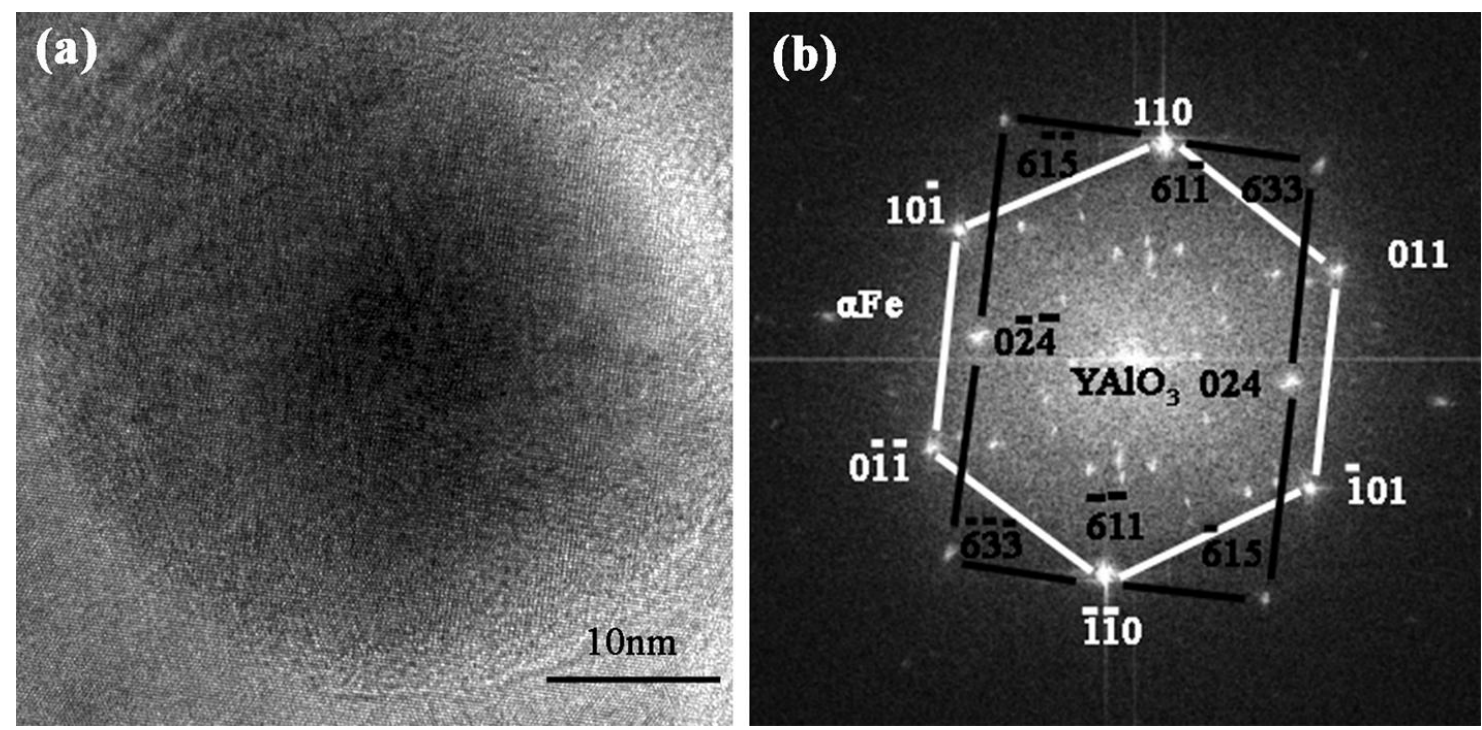

Fig. 6 

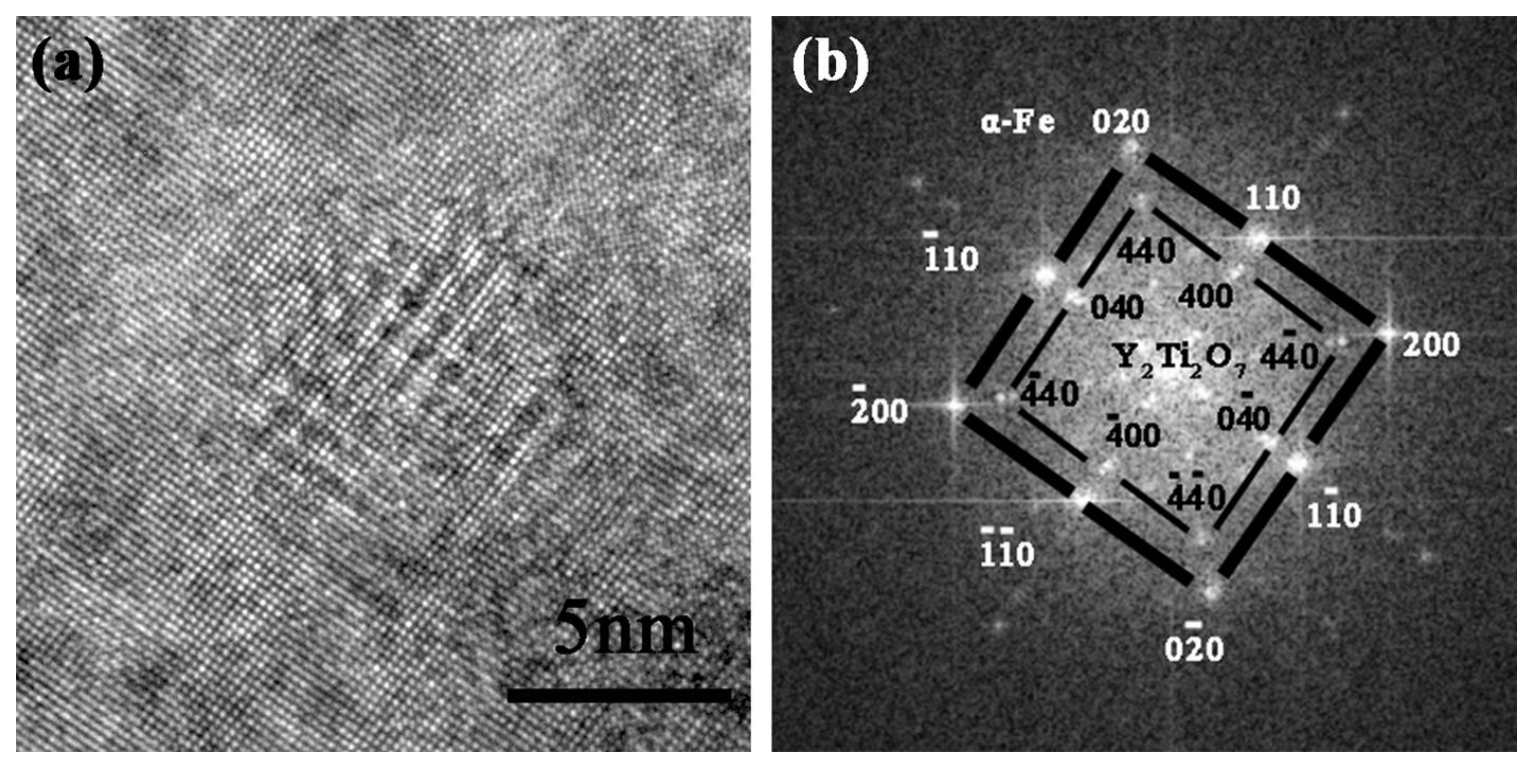

Fig. 7 


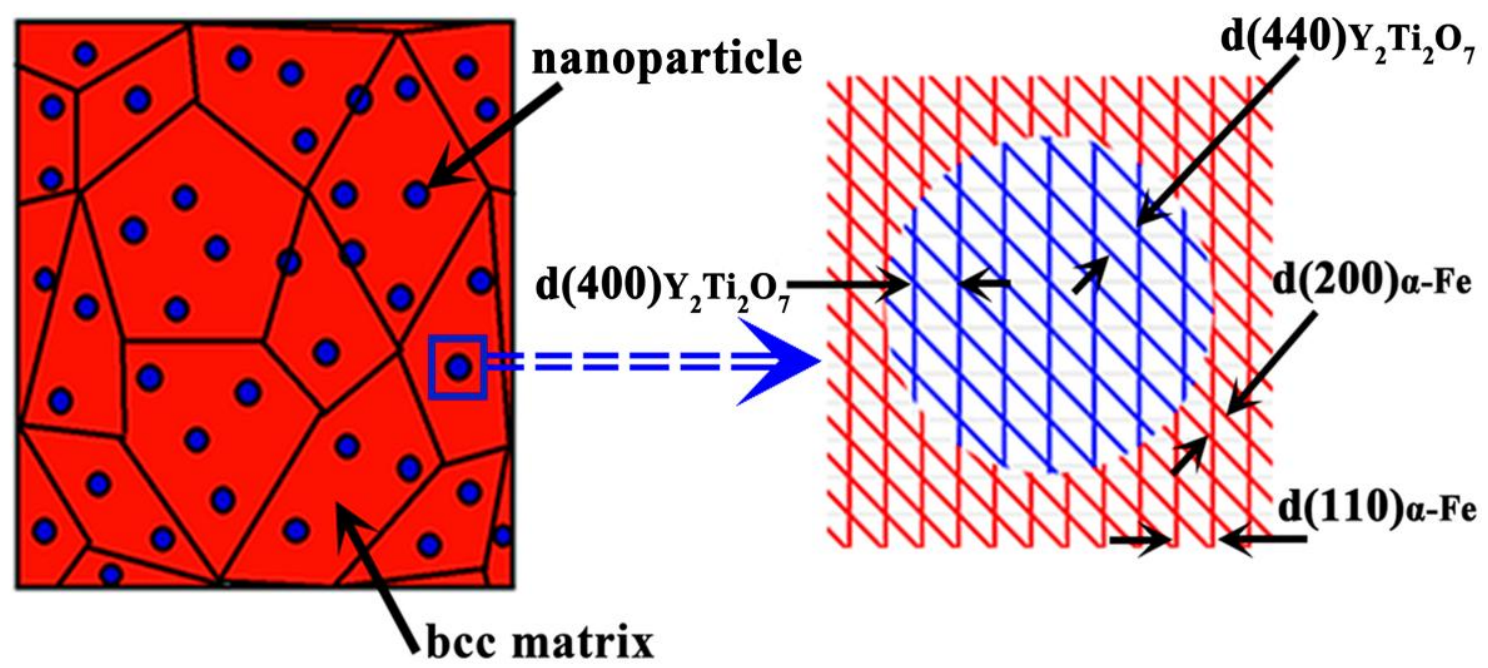

Fig. 8 

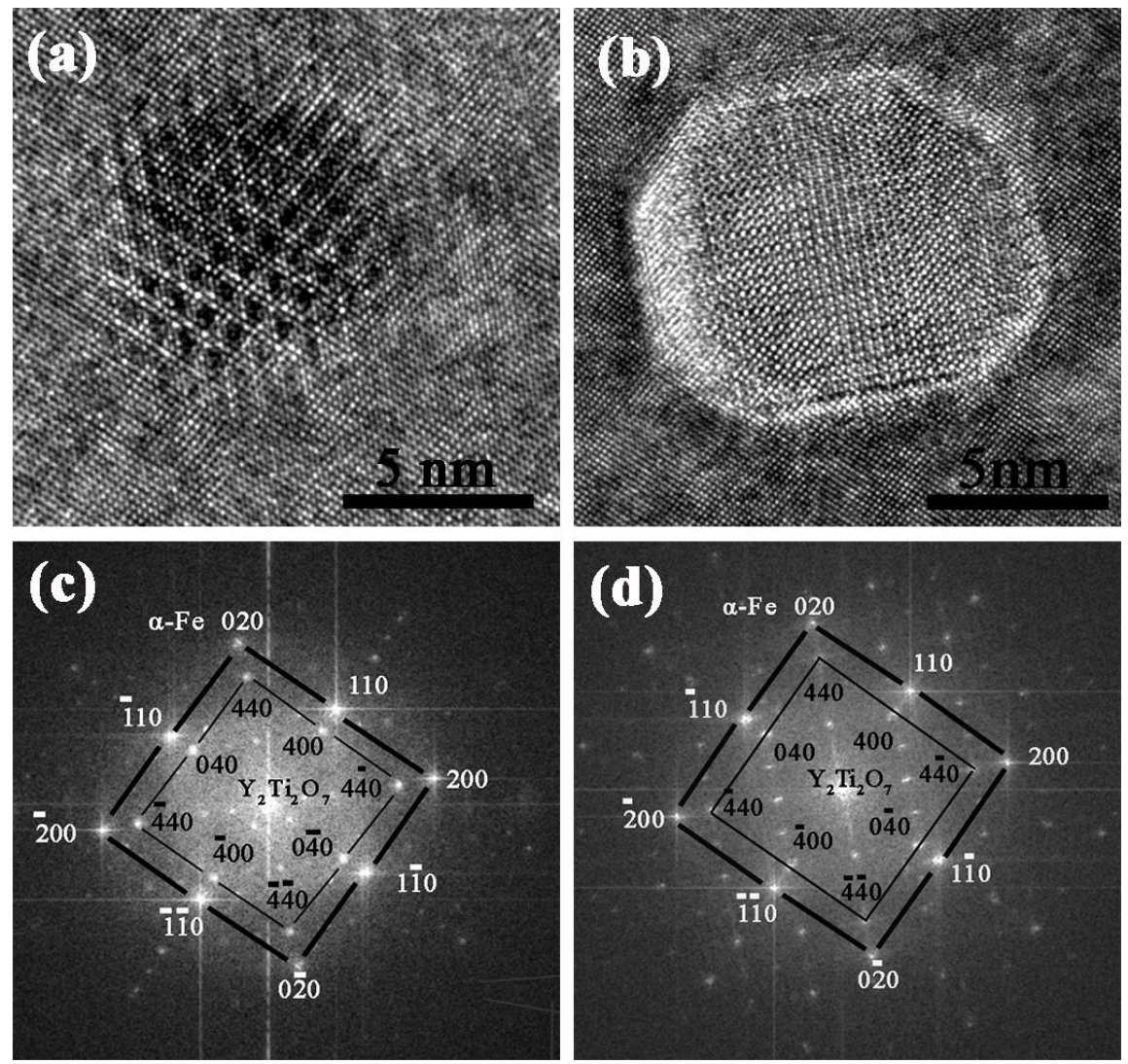

Fig. 9 


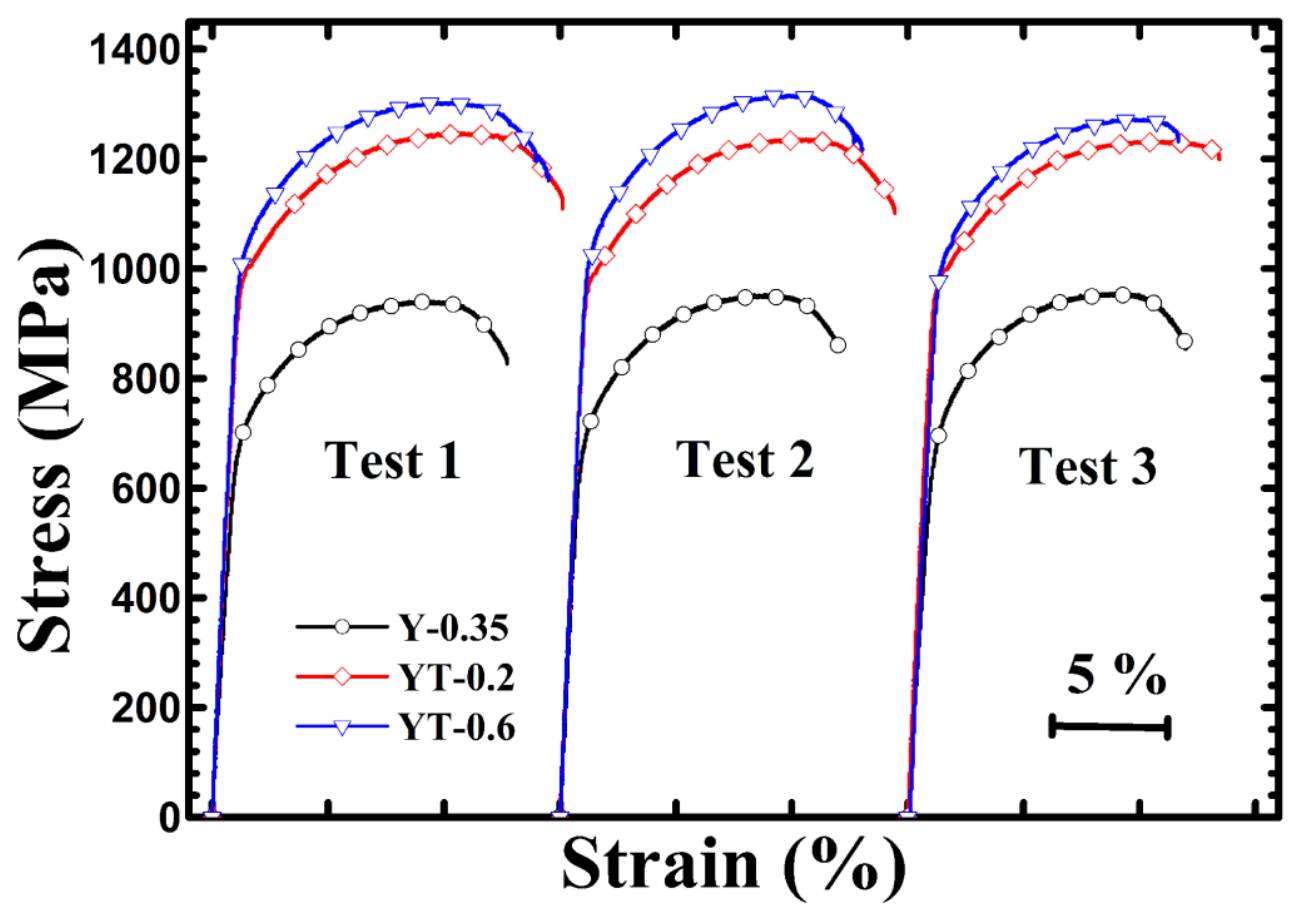

Fig. 10 
Table 1 The compositions of the model alloy and ODS steels (wt. \%)

\begin{tabular}{cccccccc}
\hline & $\mathrm{Cr}$ & $\mathrm{Al}$ & $\mathrm{W}$ & $\mathrm{Ti}$ & $\mathrm{Y}_{2} \mathrm{Ti}_{2} \mathrm{O}_{7}$ & $\mathrm{Y}_{2} \mathrm{O}_{3}$ & $\mathrm{Fe}$ \\
\hline Model Alloy & - & - & - & - & 20 & - & Bal. \\
YT-0.2 & 14 & 3 & 2 & 0.35 & 0.2 & - & Bal. \\
YT-0.6 & 14 & 3 & 2 & 0.35 & 0.6 & - & Bal. \\
Y-0.35 & 14 & 3 & 2 & 0.5 & - & 0.35 & Bal. \\
\hline
\end{tabular}


Table 2 The ultimate tensile strength, yield strength and uniform elongation of Y-0.35,

YT-0.2 and YT-0.6.

\begin{tabular}{cccccccccc}
\hline & \multicolumn{3}{c}{ Ultimate Tensile Strength } & \multicolumn{2}{c}{ Yield strength (MPa) } & \multicolumn{2}{c}{ Uniform Elongation (\%) } \\
& Y-0.35 & YT-0.2 & YT-0.6 & Y-0.35 & YT-0.2 & YT-0.6 & Y-0.35 & YT-0.2 & YT-0.6 \\
\hline Test 1 & 940 & 1247 & 1302 & 684 & 1024 & 1023 & 11.4 & 12.8 & 11.9 \\
Test 2 & 952 & 1236 & 1315 & 687 & 978 & 1024 & 10.4 & 12.1 & 11.7 \\
Test 3 & 955 & 1232 & 1272 & 690 & 979 & 994 & 10.8 & 13.2 & 11.2 \\
Average & 949 & 1238 & 1296 & 687 & 993 & 1013 & 10.9 & 12.7 & 11.6 \\
\hline
\end{tabular}




\section{Graphical Abstract}
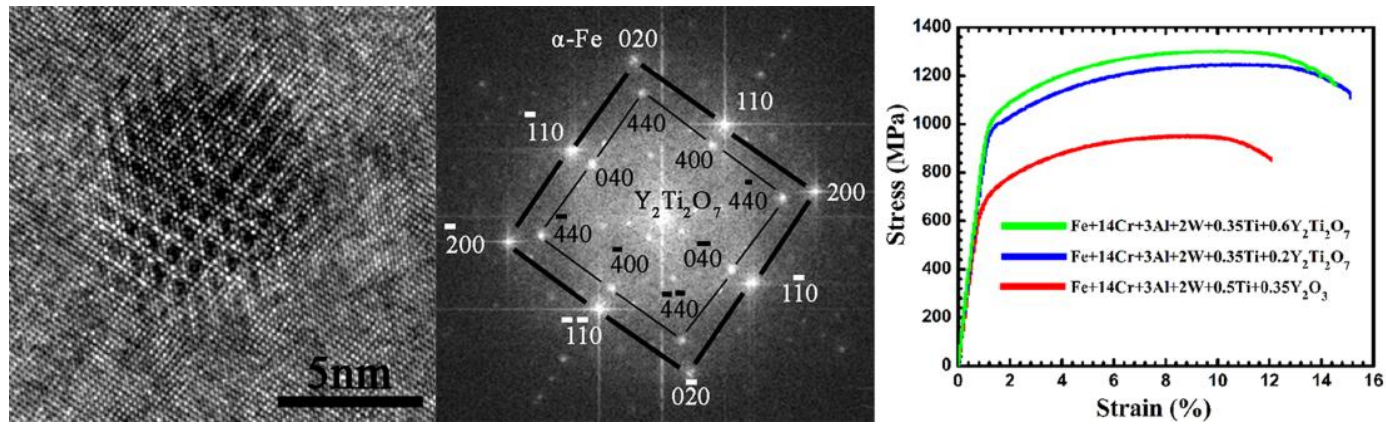

In order to improve the mechanical properties of $\mathrm{Fe}-\mathrm{Cr}-\mathrm{Al}$ ODS steels, $\mathrm{Y}_{2} \mathrm{Ti}_{2} \mathrm{O}_{7}$ nanoparticles (NPs) were added instead of the conventional $\mathrm{Y}_{2} \mathrm{O}_{3}$ NPs. These NPs crystallized with a fine size and shared a semi-coherent interface with the matrix after hot isostatic pressing of the ODS steel. The remarkably improved mechanical properties of the Al-containing ODS steels can be attributed to increasing number density of $\mathrm{Y}_{2} \mathrm{Ti}_{2} \mathrm{O}_{7}$ nanoprecipitates. 


\section{Highlights}

- $\mathrm{Y}_{2} \mathrm{Ti}_{2} \mathrm{O}_{7}$ nanoparticles were added to strengthen the $\mathrm{Fe}-\mathrm{Cr}-\mathrm{Al}$ steels.

- They were semicoherent with the matrix and prevent formation of Y-Al-O particles.

- The oxide dispersions in the $\mathrm{Fe}-\mathrm{Cr}$ - $\mathrm{Al}$ steel with 0.6 wt. $\% \mathrm{Y}_{2} \mathrm{Ti}_{2} \mathrm{O}_{7}$ were $7.4 \pm 3.7$ nm.

- The tensile strength of the $\mathrm{Fe}-\mathrm{Cr}-\mathrm{Al}$ steel with 0.6 wt.\% $\mathrm{Y}_{2} \mathrm{Ti}_{2} \mathrm{O}_{7}$ reached 1296 $\mathrm{MPa}$. 